Research Paper

\title{
An efficient, non-invasive approach for in-vivo sampling of hair follicles: design and applications in monitoring DNA damage and
} aging

\author{
Natalie Kudlova ${ }^{1,}{ }^{,}$, Hanus Slavik ${ }^{1,}{ }^{*}$, Pavlina Duskova1, Tomas Furst ${ }^{2}$, Josef Srovnal ${ }^{1}$, Jiri Bartek ${ }^{1,3,4}$, \\ Martin Mistrik ${ }^{1}$, Marian Hajduch ${ }^{1}$ \\ ${ }^{1}$ Institute of Molecular and Translational Medicine, Faculty of Medicine and Dentistry, Palacky University and \\ University Hospital Olomouc, Olomouc 779 00, Czech Republic \\ ${ }^{2}$ Faculty of Science, Palacky University and University Hospital in Olomouc, Olomouc 779 00, Czech Republic \\ ${ }^{3}$ Danish Cancer Society Research Center, Copenhagen DK-2100, Denmark \\ ${ }^{4}$ Division of Genome Biology, Department of Medical Biochemistry and Biophysics, Science for Life Laboratory, \\ Karolinska Institute, Stockholm 171 77, Sweden \\ *Equal contribution
}

Correspondence to: Martin Mistrik, Marian Hajduch; email: martin.mistrik@upol.cz, marian.hajduch@upol.cz

Keywords: hair follicle cells, non-invasive sampling, irradiation, cellular senescence, DNA damage response

Received: July 15, $2021 \quad$ Accepted: November 22, $2021 \quad$ Published: December 6, 2021

Copyright: (c) 2021 Kudlova et al. This is an open access article distributed under the terms of the Creative Commons Attribution License (CC BY 3.0), which permits unrestricted use, distribution, and reproduction in any medium, provided the original author and source are credited.

\section{ABSTRACT}

In accordance with the 3 Rs principle (to replace, reduce and refine) animal models in biomedical research, we have developed and applied a new approach for sampling and analyzing hair follicles in various experimental settings. This involves use of a convenient device for non-invasive collection of hair follicles and processing methods that provide sufficient amounts of biological material to replace stressful and painful biopsies. Moreover, the main components of hair follicles are live cells of epithelial origin, which are highly relevant for most types of malignant tumors, so they provide opportunities for studying aging-related pathologies including cancer. Here, we report the successful use of the method to obtain mouse hair follicular cells for genotyping, quantitative PCR, and quantitative immunofluorescence. We present proof of concept data demonstrating its utility for routine genotyping and monitoring changes in quality and expression levels of selected proteins in mice after gamma irradiation and during natural or experimentally induced aging. We also performed pilot translation of animal experiments to human hair follicles irradiated ex vivo. Our results highlight the value of hair follicles as biological material for convenient in vivo sampling and processing in both translational research and routine applications, with a broad range of ethical and logistic advantages over currently used biopsybased approaches.

\section{INTRODUCTION}

Hair follicles provide a very accessible source of biological material that can be non-invasively obtained from most mammals $[1,2]$. Such material is particularly valuable for experiments with rodent models involving repeated sampling that currently require multiple invasive biopsies, which are relatively laborious and stressful for the animals [3]. Replacement of blood or skin tissue collection would also be convenient for specific examinations in human medicine [4-6]. This micro-organ structure also has other advantages in biomarker studies, including suitability for investigations of circadian rhythms [5, 7], and the presence of numerous cell types in a small area, which can be easily distinguished, such as keratinocytes, melanocytes, or 
perifollicular macrophages and mast cells [8-10]. However, the epithelial component of the follicles is the most promising for biomarker investigations because most neoplastic diseases have an epithelial origin.

Here, we present a proof of concept study involving use of a newly designed and constructed device allowing collection of large amounts of murine hairs with their hair roots containing follicular cells. We also demonstrate that DNA, RNA, and proteins in the collected hair follicle cells can be conveniently analyzed using standard cell and molecular biology methods such as genotyping, qPCR, and immunofluorescence analyses. The study focused on changes associated with the DNA damage response (DDR), especially double-strand breaks, and cellular senescence both in naturally aged tissue and induced using ionizing radiation (IR).

\section{RESULTS}

\section{Design of the follicular cells' collector}

The device we developed sucks hair from skin by vacuum suction. It uses removable disposable forceps of inert fixation-compatible material; forceps are made from a pair of modified pipette tips of different sizes (one inside the other). The bigger pipette tip is connected to a pistol-like device and covers the smaller tip connected to a piston. The smaller tip clicks into the bigger one by piston push, thereby firmly gripping the sucked hairs. The tip is removed from the pistol by a further push of the piston and stays attached to the skin via the squeezed hair. The forceps with gripped hairs are then manually removed. The removed hairs include follicles composed of multiple live follicular cells (Figure 1). Approximately 200 mice hairs can be

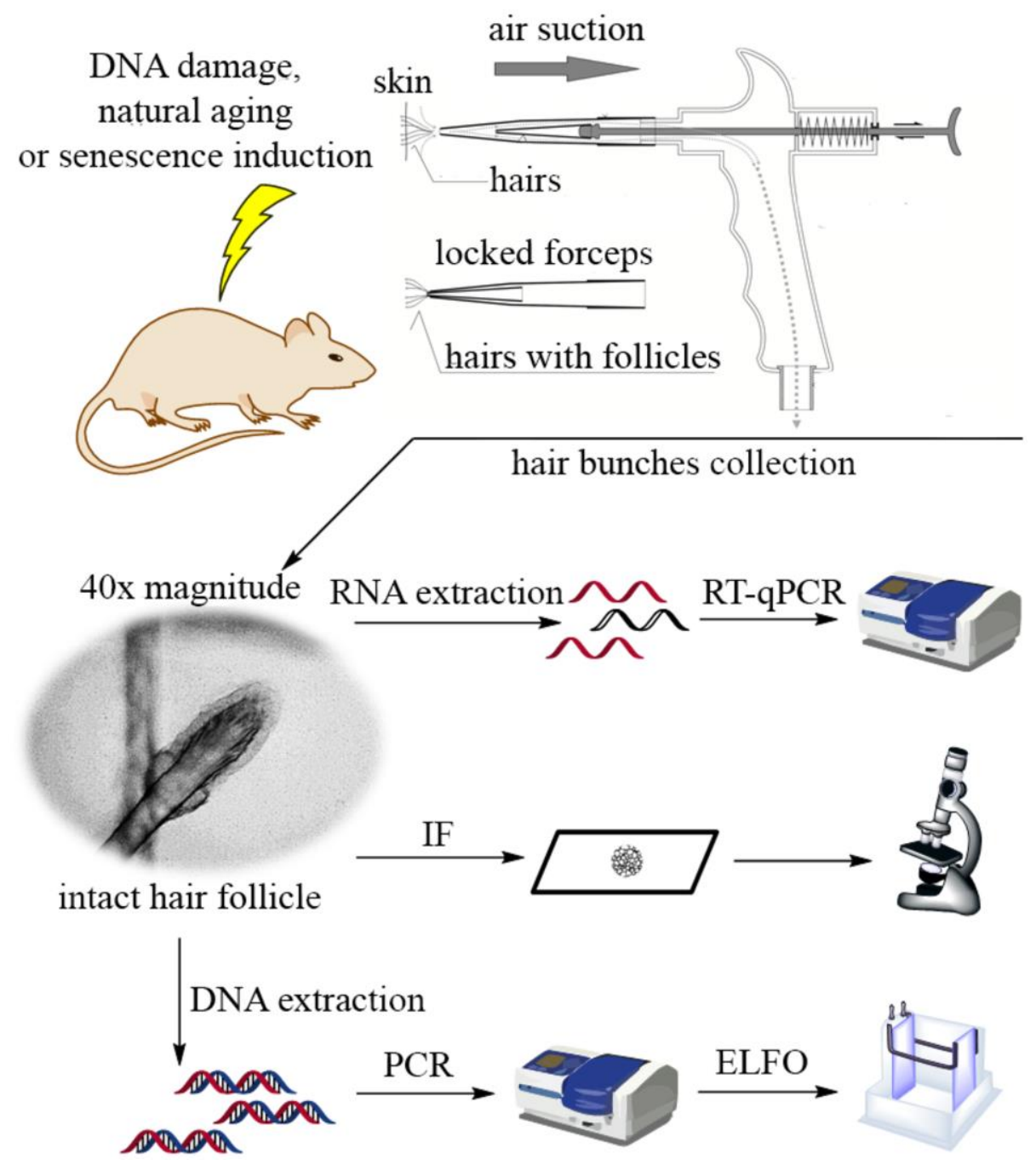

Figure 1. Design of the customized suction-based collector of hair follicle samples and scheme of the experimental workflow in the study. 
removed in a single sample and each follicle contains approximately 50 cells. Inert and disposable forceps allow easy manipulation and immediate processing of the sample by fixation or lysis. The process is fast, easy, and does not involve touching the hair (Supplementary Video 1). Other advantages of the method include noninvasiveness, allowing many repetitive multi-site collections with minimal stress to the experimental animals.

\section{Pre-processing of murine hairs}

Hair follicles are morphologically intact and can be easily recognized during microscopic evaluation (Figure $2 \mathrm{~A})$. Collected hairs can be stored in a dry state or suitable medium, e.g. for nucleic acid extraction. We obtained median yields of 275 and $486 \mathrm{ng}$ of total RNA and DNA per pluck of hairs obtained with our collection device according to analyses with a NanoDrop 1000 Spectrophotometer (Thermo Fisher Scientific). Moreover, the quality of RNA is usually high and suitable for further analyses with a RIN (RNA integrity number) of ca. 8 units according to analysis with an Agilent Bioanalyzer 2100. Thus, we consider DNA and RNA yields and qualities, presented in Figure 2B, sufficient for further experiments. There is no need for any special processing steps such as homogenization for isolating nucleic acids or cutting slices for microscopic analyses, and the material can be collected and processed repeatedly, within short times and in high amounts, from mice.

\section{Genotyping of collected follicular cells fully replaces tail biopsies}

Genotyping is one of the most common reasons for biopsy in research and commercial procedures involving genetically modified mice. Usually, a tip of the tail or an ear punch is collected from the examined mice to obtain DNA for analysis. To minimize pain and stress, the ethical standards of many countries require anesthesia before the collection, which complicates and prolongs the procedure. Here we show, that follicles collected by the specialized device described above can fully substitute tail tip biopsies. 5XFAD mice commonly used as a model for Alzheimer's and senescence-related diseases [11, 12], were used for proof of this concept. We compared the genotyping results from 151 tail biopsies and 151 hair samples from the offspring of 5XFAD transgenic males and C57Bl/6 females. For this, we assessed by PCR the presence or absence of two genes carried by the transgenic mice: APP695 (APP, encoding an amyloid-beta [A4] mouse/human chimeric precursor protein) and PSEN1 (PST, encoding human presenilin 1). Results obtained with DNA samples from hair bunches and tail biopsies were fully consistent (presence of both transgenes or absence of both, with no sample showing presence of only one of the transgenes). Thus, hair follicles could apparently fully replace tail biopsy for genotyping, with no loss of accuracy. Results of electrophoretic separation analysis demonstrating the transgenes' presence or absence are shown in Figure 3.

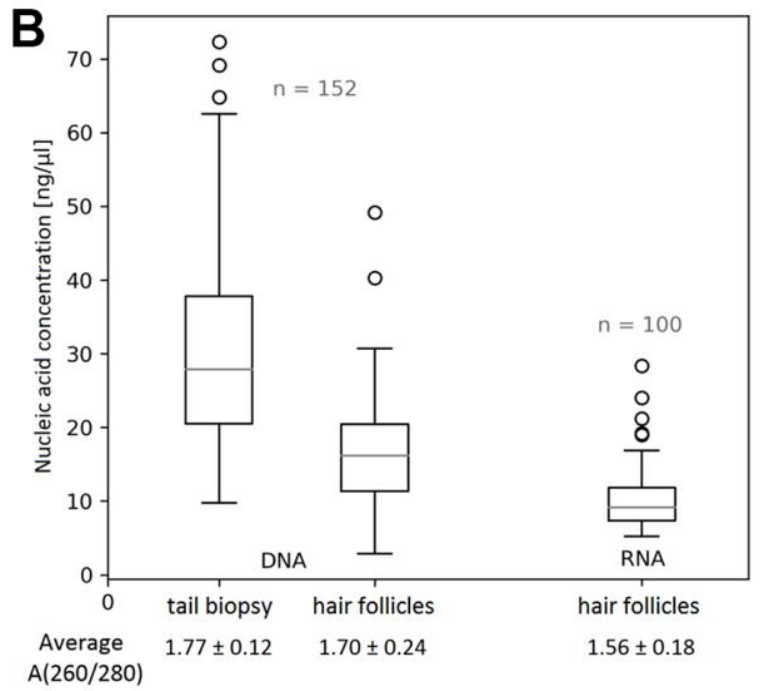

Figure 2. Murine hair follicles as starting material. (A) Representative images of hairs highlighted with Giemsa - Romanowsky staining (and indicated magnification) showing intact hair follicles obtained by sampling with our vacuum collector. (B) Comparison of DNA isolation results from hair follicles obtained with our device and common tail biopsies, and yields of RNA isolated from hair follicles. The quantity and quality of all nucleic acid samples, in $30 \mu$ l solutions, were measured using a ND 1000 Spectrophotometer. Data are presented as boxplots showing median, maximum and minimum values, their quartile distribution, interquartile range, and outlier values. 


\section{Downstream transcriptional DNA damage response in hair follicle cells after gamma irradiation in-vivo}

Gamma irradiation, the most common mode of cancer treatment, causes complex responses in exposed cells called the DNA damage response (DDR). The DDR involves multiple transcriptional and posttranscriptional changes which are intensively investigated in cancer studies, and quantitative evaluation of DDR can be used for quick assessments of radiation exposure, radiotherapy monitoring, and identification of radiosensitive individuals $[2,13,14]$. Three commonly used markers (p21,SESN1, and MDM2) in the ATM/CHEK2/p53 pathway, which directly responds to DNA damage, were tested for acute radiation response by RT-qPCR. The stability of their expression in the absence of IR was checked and $p 21$ showed the least variability between samples obtained on multiple occasions (significance of between-time differences: $p=0.530$ ). In contrast, there were significant between-time differences in SESNI expression in irradiated samples and even in the absence of IR ( $\mathrm{p}=0.025)$. We also consider SESNI an inappropriate marker for monitoring hair follicles after IR because it has very low basal expression (late $\mathrm{Ct}$ values or negativity). However, there was significant upregulation of SESN1 30 minutes after IR and downregulation after $24 \mathrm{~h}$, especially at the highest doses (Figure 4). In further contrast, MDM2 showed a much more stable amplification pattern, but very weak dependence on IR. Thus, $p 21$ provided the most valuable

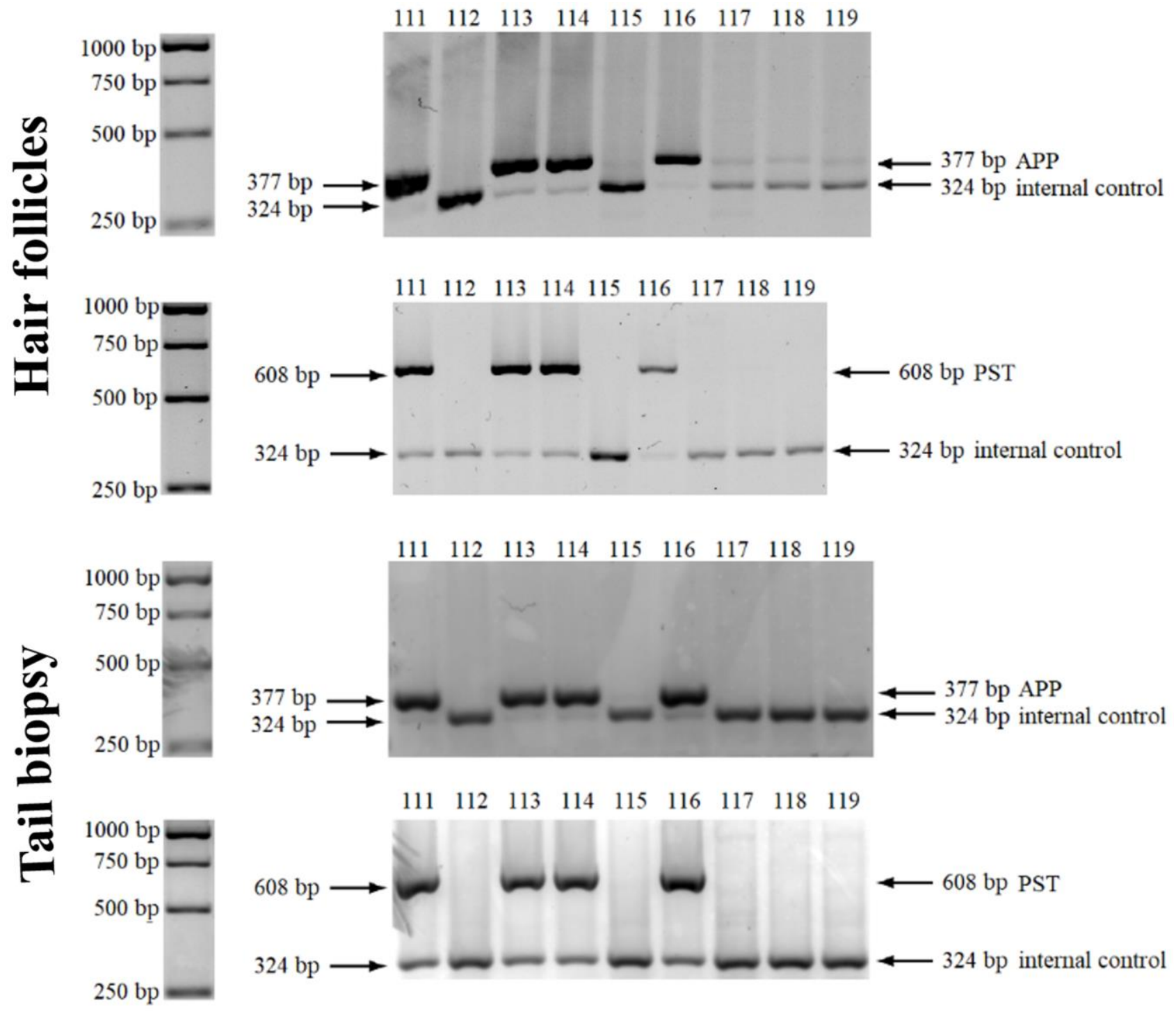

Figure 3. Genotyping using murine hair follicles. Results of PCR-agarose gel electrophoresis showing the presence or absence of $A P P$ and PST transgenes in representative samples (from mice 111 - 119), of both biological materials - hair follicles and tail biopsies. A $1 \mathrm{~kb}$ GeneRuler DNA ladder is presented on the left side. 
amplification pattern, with the lowest variability and highest potential for distinguishing samples subjected to different IR doses and/or collected at different times. We observed a 2.5 median fold change $\left(\mathrm{FC}_{\mathrm{m}}\right) 30 \mathrm{~min}$ after a 2 Gy dose, followed by a reduction to -1.54 after $24 \mathrm{~h}$ (Figure 4). A 6 Gy dose induced a longer response, with $\mathrm{FC}_{\mathrm{m}}=1.81$ at $30 \mathrm{~min}$ after radiation, and no observed reduction until the $6 \mathrm{~h}$ time-point $\left(\mathrm{FC}_{\mathrm{m}}=1.94\right)$ and slight reduction to $\mathrm{FC}_{\mathrm{m}}=1.24$ at the $24 \mathrm{~h}$ time point. The 10 Gy dose even induced an increase between the $30 \mathrm{~min}$ and $6 \mathrm{~h}$ time points $\left(\mathrm{FC}_{\mathrm{m}}=2.25\right.$ and 3.71, respectively). In summary, $p 21$ showed the most significant increase $(\mathrm{p}$ $<0.01$ ) until $6 \mathrm{~h}$ after IR at all tested doses (Figure 4), with clear between-dose distinctions at some time points (with higher doses inducing higher $\mathrm{FC}_{\mathrm{m}}$ values, except at the initial sampling point, 30 min after IR). In summary, our data provide some proof of concept by showing that our device and protocols can detect changes in expression patterns induced by external factors.

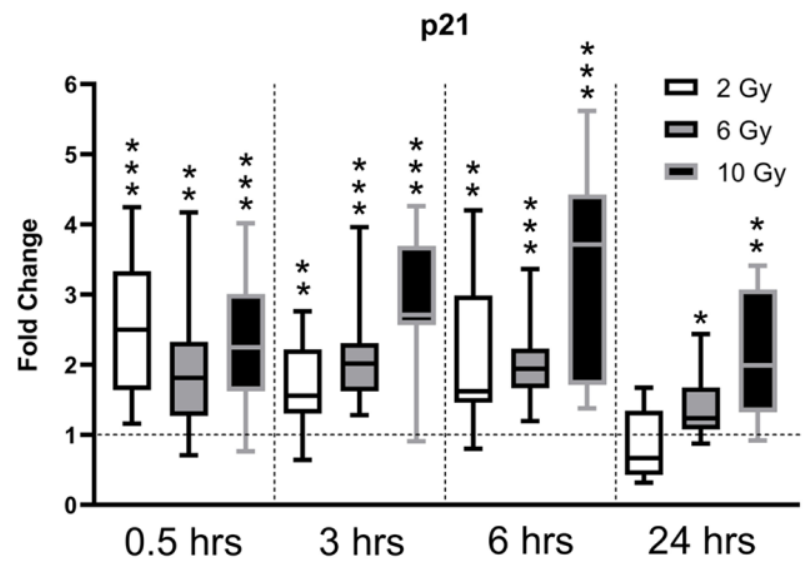

MDM2 X1 variant

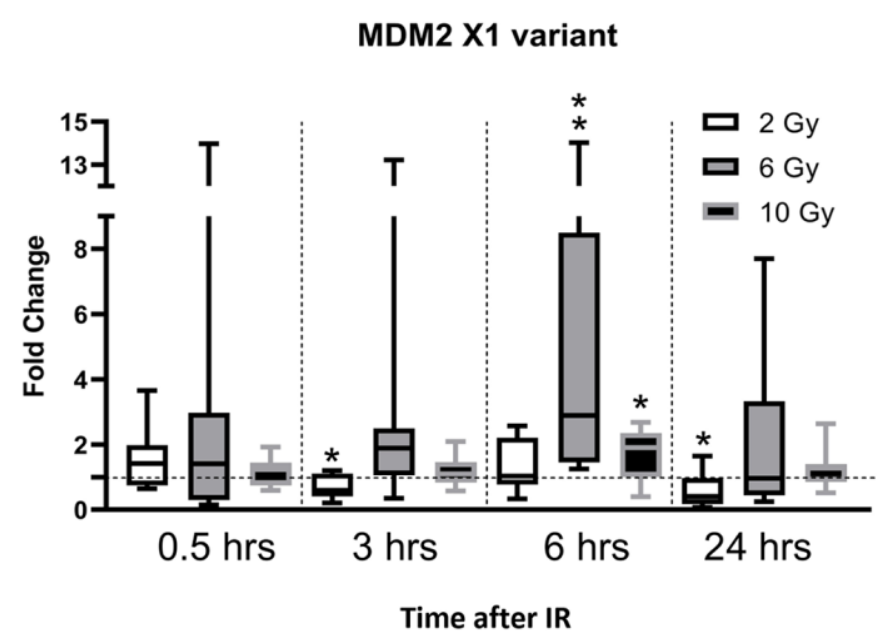

Time after IR

\section{Immunofluorescence (IF) analysis of $\boldsymbol{\gamma}$-H2AX lesions after gamma irradiation}

In the previously mentioned ATM/CHEK2/p53 pathway and DDR, ATM kinase is directly recruited to DNA damage sites, where it phosphorylates histone $\mathrm{H} 2 \mathrm{AX}$ on serine S139, forming $\gamma-\mathrm{H} 2 \mathrm{AX}$ detectable as the immunofluorescent foci pattern in nuclei (Figure 5A detail). We identified typical intense foci in the nuclei of irradiated hair follicles (Figure 5A). An IDD (intensity of DNA damage) value was calculated, as described in the methods section, for each hair follicle projection as averages from $\mathrm{z}$-stack imaging (Figure 5B). Three to five morphologically intact follicles from each sample were scanned and analyzed. There were no statistically significant differences between measurements from either the same or different mice under defined conditions. Thus, we did not detect any inter-individual variability and there was no distinction between

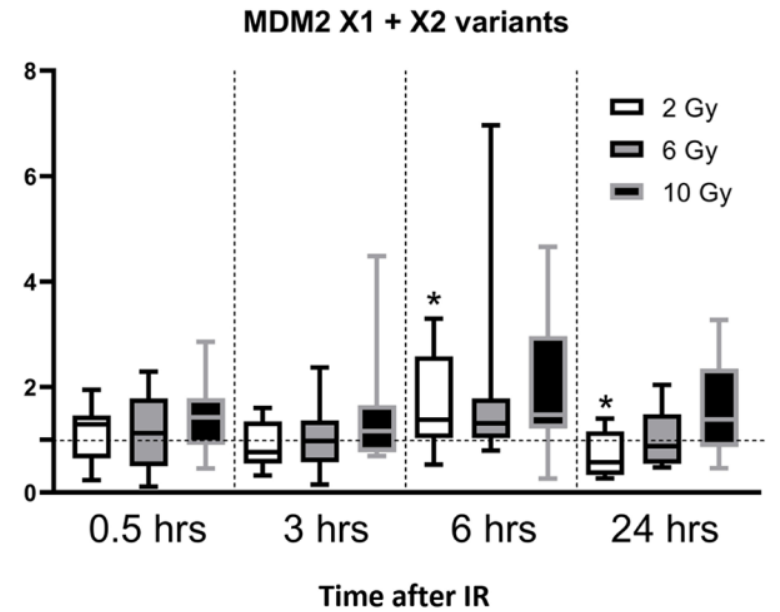

Figure 4. Gene expression changes (mRNA level) in murine hair follicles after in vivo ionizing irradiation. Data are expressed in boxplot graphs showing median, first quartile data distribution and maximum and minimum values of fold changes relative to expression at time zero (immediately before irradiation) normalized using HPRT mRNA levels. Results of paired t-tests of the significance of differences between indicated groups and times (relative to the zero-time point) are also depicted $\left({ }^{*} p<0.05,{ }^{*} p<0.01,{ }^{* * *} p<0.001\right)$. 
biological and technical replicates in further calculations. The low numbers of subjects in our experiments $(n=5$ per condition) may have contributed to this, but they were sufficient for clear quantitative resolution of samples differing in radiation dose and/or time after IR. There was a strong increase in IDD shortly after irradiation, with a gradual reduction during the following $24 \mathrm{~h}$. The IDD was also quantitatively dependent on dose, with clear separation between samples given 2 Gy from those given 6 and $10 \mathrm{~Gy}$ doses. Thus, the direct DDR after IR quantitatively differed between doses, but followed similar dynamic patterns under all three doses, in the murine hair follicles (Figure 5C). Not only recognizable foci were detected, but also areas with continuous green $\gamma-\mathrm{H} 2 \mathrm{AX}$ signal, which we attributed to apoptotic lesions, based on previous reports [2] and their general occurrence in samples from mice given the 10 Gy treatment. The 10 Gy treatment also resulted in lower IDD values than the 6 Gy treatment, possibly due to cell damage exceeding thresholds allowing proper quantification, although there was no significant difference between 6 Gy- and 10 Gy-treated samples at any time point. The other between-dose differences in samples collected $30 \mathrm{~min}, 3 \mathrm{~h}$, and $6 \mathrm{~h}$ after IR were significant according to the Kruskal-Wallis nonparametric test with multiple comparisons.

Apart from gamma irradiation, we tested also the possibility to induce DDR after topical application of chemical clastogens. To address such an option, we dissolved DNA damaging agents bleomycin and cisplatin in DMSO and applied them directly to small areas of the skin of tested animals. Collected hair follicles from the exposed areas indeed showed increased $\gamma-\mathrm{H} 2 \mathrm{AX}$ staining in the nuclei compared to the control areas (Supplementary Figure 3). These data confirm that the topical application of various chemical compounds and direct assessment of their effects in follicular cells in-vivo is possible which enriches the portfolio of applications of the method significantly.

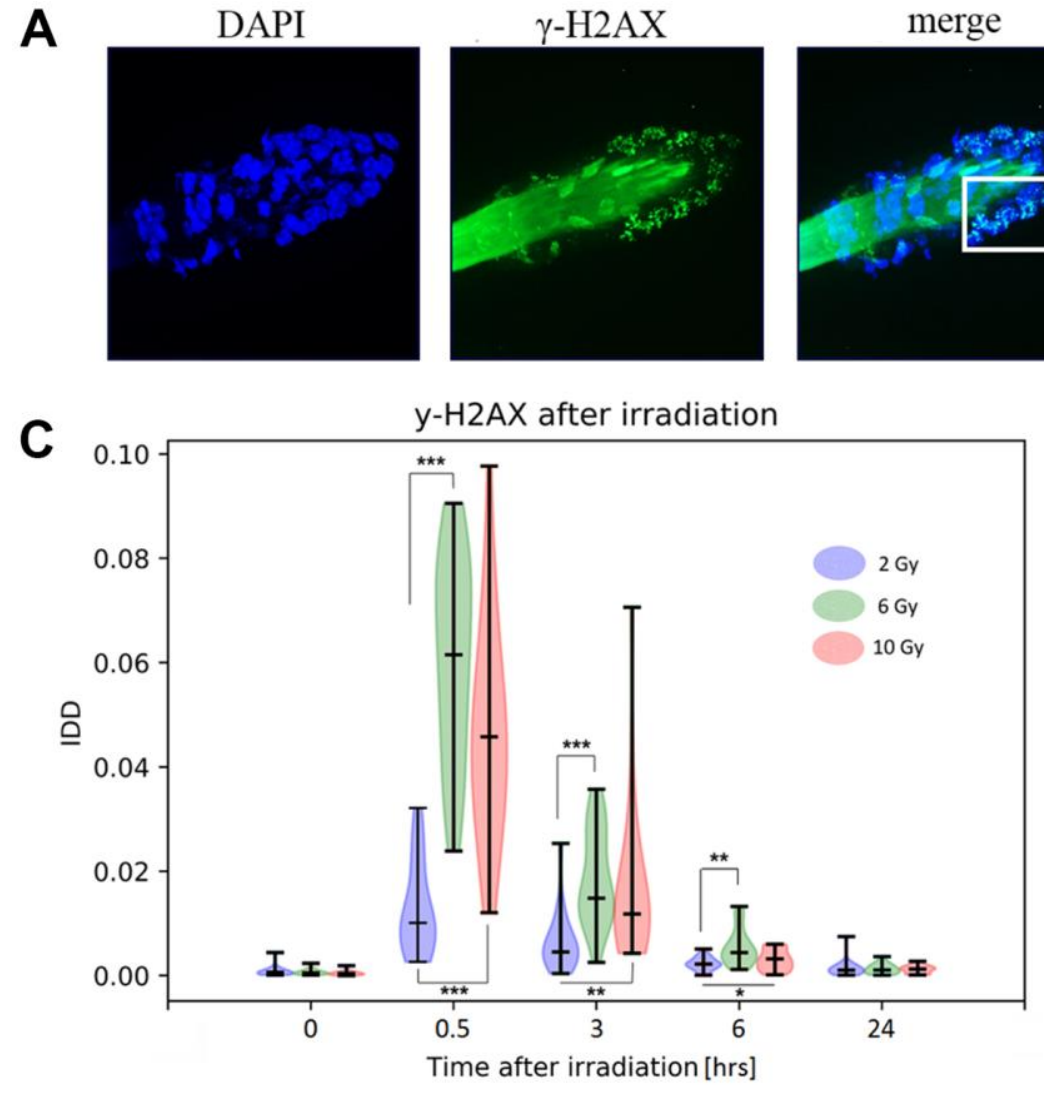

B
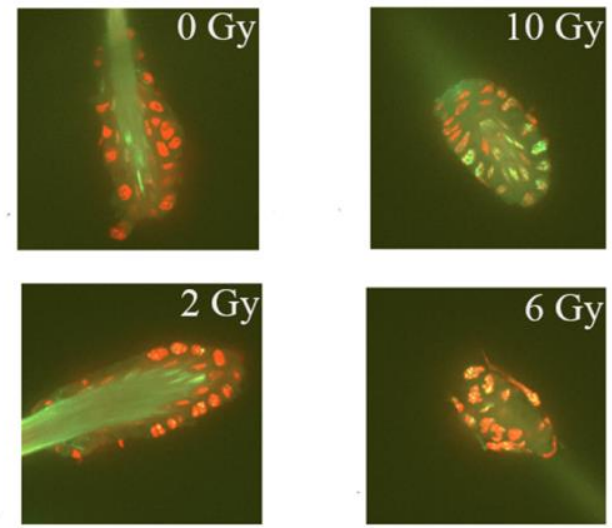

Figure 5. Immunofluorescent detection of $\mathbf{Y}-\mathrm{H} 2 \mathrm{AX}$ in murine hair follicles. (A) Representative images of a follicle after ionizing irradiation, extracted as maximum intensity projection from z-stack scanning by confocal spinning disc microscopy. Nuclei stained with DAPI and $\mathrm{\gamma}-\mathrm{H} 2 \mathrm{AX}$ foci and hair shaft autofluorescence are visible in the green channel. (B) Representative images used in the computational analyses of one z-stack layer, the red color of the nuclei (DNA) was selected artificially to maximize the visibility of green $\mathrm{\gamma}$ - $\mathrm{H} 2 \mathrm{AX}$ foci. (C) Results of image analyses in terms of IDD (intensity of DNA damage), with each data point representing the area of the $\gamma$-H2AX signal related to the area of the nuclei in one scanned hair follicle in z-stack mode. Probability density of the data, maximal and minimal values, medians, and results of a multiple Kruskal-Wallis test $(* p<0.05, * * p<0.01, * * * p<0.001)$ are showed in violin plots. 


\section{Expression patterns of selected markers in mice hair follicular cells reflect their biological age}

Senescent cells are commonly identified by increases in senescence-associated $\beta$-galactosidase $\quad(\mathrm{SA}-\beta$-gal) activity [15-17], but assays of this activity have multiple limitations [18]. In contrast, p16 and $p 21$ have known senescence-associated activities and functions [19-21], and their expression is highly elevated in a wide variety of human and mouse senescent cell lines, so we used them as biomarkers for our age-related senescence measurements [22-24]. qPCR analyses of p16 and $p 21$ expression levels using the acquired cDNA samples revealed significant differences in these two senescence biomarkers' expressions. Inter alia, there were strong differences in gene expression between young ( 6 months old, $n=6)$ and old (2.5-3 years old, $\mathrm{n}=6$ ) animals (Figure 6A) with $\mathrm{p}<0.05, \mathrm{p}<0.01$ or
A

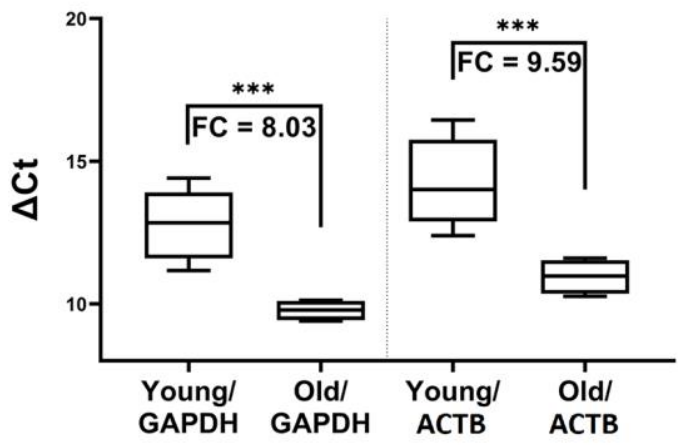

p21

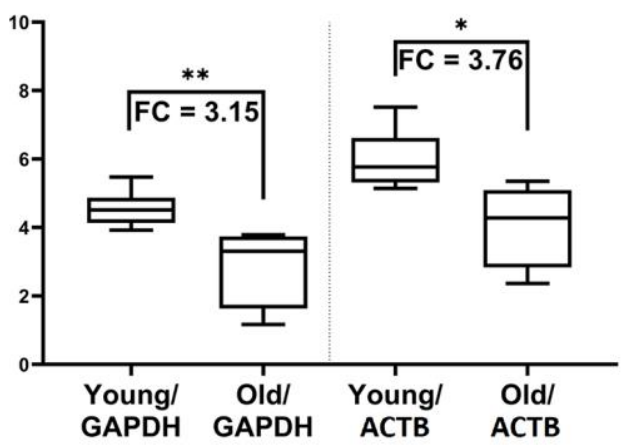

B
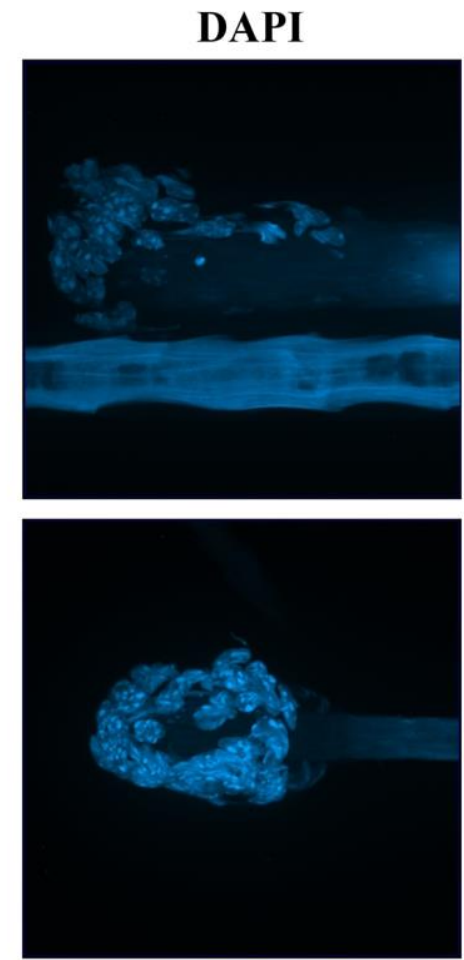

p16
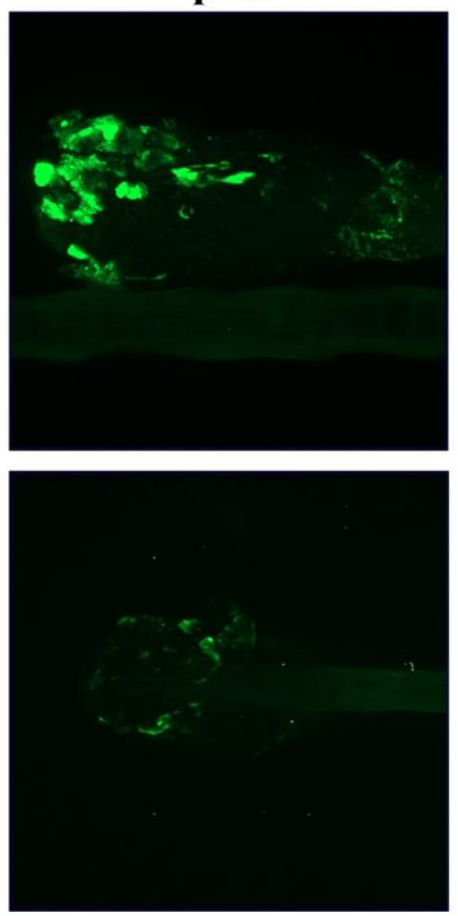

merge
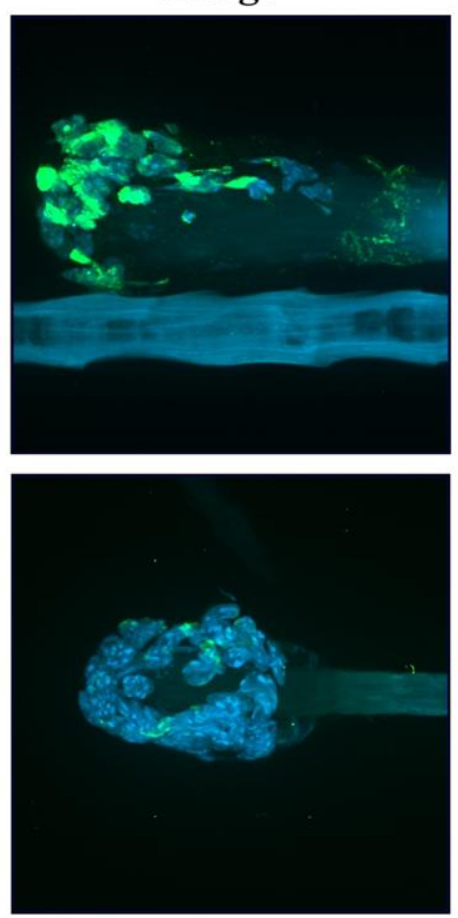

Figure 6. Markers of senescence analysis in hair follicular cells. (A) $p 16$ and $p 21$ gene expression (mRNA level) in hair follicles from young mice ( 6 months old) and old mice (2.5-3 years old) in boxplot graphs of $\triangle$ Ct values normalized using GAPDH or ACTB. Graphs show medians, first quartile data distribution, minimal and maximal points, and fold change values as a specifying detail. Results of a t-test are also shown ( $\left.{ }^{*} p<0.05,{ }^{* *} p<0.01,{ }^{* *} p<0.001\right)$. (B) Representative images showing the higher p16 protein levels in murine hair follicles of old animals relative to those of young animals. Images were obtained from z-stack scanning with a confocal spinning disc microscope. DAPIstained nuclei are shown in the blue channel and p16 signals in the green channel. Autofluorescence can be seen in a hair shaft. Magnification 60x objective with oil immersion. 
$p<0.001$ depending on the housekeeping gene used for the data normalization and the target gene. Fold change differences in expression between the young and old animals of 8.03 and $9.58(\mathrm{p}<0.001)$ were calculated for the $p 16$ marker, and $3.15(\mathrm{p}<0.01)$ and 3.76 ( $\mathrm{p}<0.05)$ for $p 21$. Naturally, no significant difference in expression of target senescence markers was detected using animals with the age difference of just a few months (data not shown). To support our qPCR data, we confirmed the changes in p16 expression at the protein level using immunofluorescence assays and the same mice cohort, which showed that cells from the older animals had higher levels of p16 protein (Figure 6B).

\section{Radiation-induced senescence detection in murine hair follicles}

The number of senescent cells in tissues can also be increased artificially by exposure to various DNA damaging factors. Gamma radiation is a very wellknown inducer, and even mildly dosing of cells or animals can generate detectable senescence features $[25,26]$. In addition, patients who have undergone anticancer chemo- and/or radiotherapy typically have higher numbers of senescent cells than non-treated counterparts of the same chronological age [27, 28]. We detected clear irradiation-dependent senescence induction in a mouse model, as irradiated soft tissue in the right hind leg acquired more senescent cells (according to expression levels of the p16 and p21 markers) than control tissue in the left hind leg. Hair follicles were collected at seven time-points (the first before IR) from the left and right hind legs of 10 mice. Significant elevation in expression of the selected p16 and p21 markers was observed in irradiated legs from 21 and 28 days after IR, respectively, relative to levels in samples collected directly before IR. Both markers remained constantly up-regulated until the last sampling time (35 days after IR), clearly indicating that senescence was induced in the irradiated tissue. The quantitative changes were not very strong, the highest observed $\mathrm{FC}_{\mathrm{m}}$ was 2.26 , for the p16 marker 21 days after IR. However, the changes were significant $(\mathrm{p}<0.01)$ at all of the last three sampling times for p16 expression. The other marker, $p 21$, showed weaker potential for discrimination between senescent and normal tissue in mice using hair follicle samples, with $\mathrm{FC}_{\mathrm{m}}$ peaking at $1.25,28$ days after IR ( $\mathrm{p}$ a 0.05 ). The expression of both markers remained unchanged in hair follicles of the control left legs during the experimental investigations (Figure 7). Those findings prompted the idea of using hair follicle cells as a murine irradiation-induced senescence model for studying senescence markers, aging experiments, and in vivo senolytic drug identification.

\section{DISCUSSION}

To meet ethical standards, experiments involving laboratory animals should be designed to obtain maximum information while minimizing stress, and ideally, they should be replaced wherever possible. Unfortunately, they cannot currently be replaced by alternative assays in numerous applications in basic and pre-clinical research. However, we present here a simple method for obtaining biological material in the
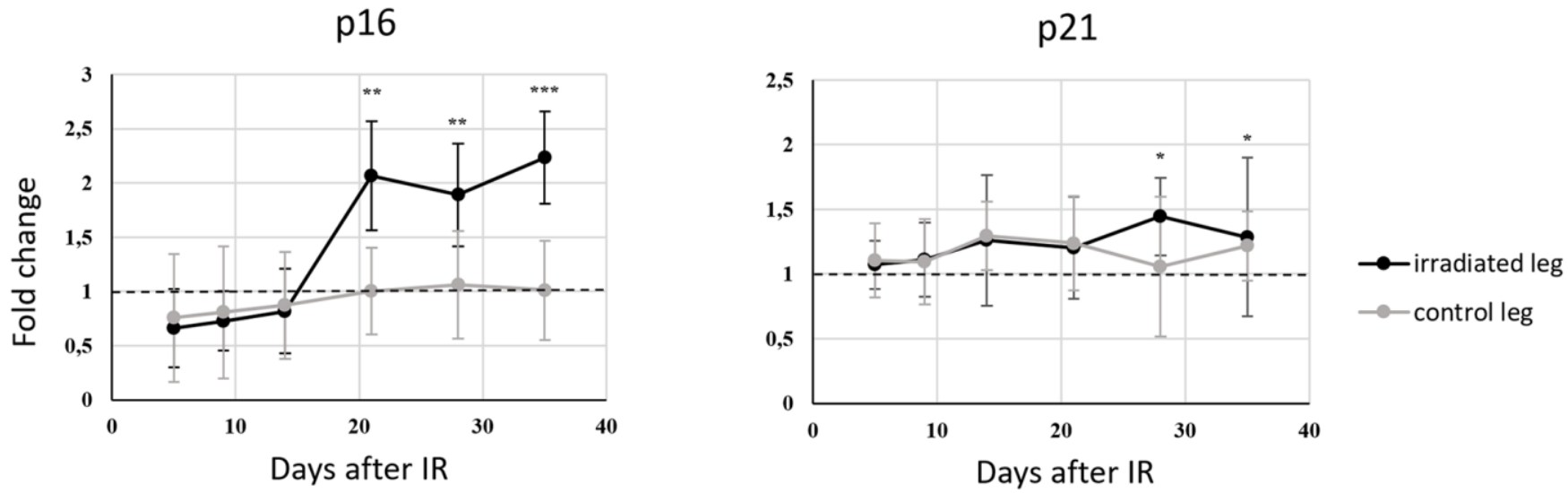

Figure 7. Changes with time in p16 and p21 gene expression (mRNA level) in murine hair follicles after a fractionated dose of $3 \times 8$ Gy applied in vivo to the right hind leg of a mouse, using each animal's left hind leg as a control. Data are expressed as fold changes relative to expression at the zero-time point (shortly before irradiation) normalized using GAPDH mRNA levels. Means and standard deviations are shown. $\Delta$ Ct values from certain time points were compared using paired t-tests and relevant time points on curves are marked with asterisks $(* p<0.05, * * p<0.01$ and $* * * p<0.001)$. 
form of follicular cells from laboratory mice with sufficient quantities and quality for multiple analyses using standard modern molecular biology methods. The material has numerous advantages, including the convenience, non-invasiveness, and repeatability of the sample collection together with its contents of cells of epithelial origin and distal tissue, as well as the ease of exposing follicular tissue to test substances with topical applications (Supplementary Figure 3). The biggest limitations of follicular cell collection in the past were the complex logistics involved in processing the samples. Ordinary tweezers and forceps used in previous setups are extremely impractical with a high risk of cross-contamination, thus this material has been used in relatively few studies. We have circumvented these limitations by using our simple device, which enables a fast, convenient collection of follicular cells. The speed by which the samples can be collected and processed (e.g. by fixation) is among the biggest advantages of our solution as it can be performed within seconds. This fact limits any potential underlying cellular responses and additional DDR caused by cofounding stressing factors related to the withdrawal process [2]. To corroborate the method's practical utility, we selected three applications. First, we proved that a sample of mouse hairs collected using disposable forceps in less than a minute (Supplementary Video 1) provides enough DNA for analysis by standard genotyping methods developed for tail tip biopsies or ear punches. As millions of laboratory mice are routinely genotyped globally every year this approach represents a major ethical and logistic breakthrough. Compared to such standard methods of biological biopsies (including phlebotomy) the amount of distress to the laboratory mice is relatively low caused mostly by the animal hand-grip as there is no visible pain reaction during the process of hair withdrawal (no twitching and/or squeaking). The absence of pain is supported also by the fact that the mice hair roots are, compared e.g. to humans, embedded relatively shallowly in upper skin layers $[4,10,29]$ and very little strength is necessary for the withdrawal process.

Although hair samples have been previously used for that purpose [29-31], our sample collection approach may motivate researchers to use them more routinely and widely.

As we showed, mRNA can also be obtained from the collected samples in sufficient quantity and quality, so we designed another set of experiments in which we monitored changes in the expression of selected genes using qPCR. We targeted genes that respond to DNA damage caused by gamma irradiation and genes whose expression changes during oncogenesis. The DDR is intensively studied in carcinogenesis and cancer treatment research. IR markers often respond differently in different biological materials, so there is no universally optimal marker that consistently provides quantitative responses, especially on the mRNA level. However, acute DDR has been detected accurately and dose-dependently by monitoring the dynamics of $p 21$ in previous studies [14, 32-34]. We dedicated $p 21$ as a suitable marker for gene expression measurements in hair follicles. It is also known that responses to IR differ and topically applied drugs can be more meaningfully evaluated using hair follicles than blood samples [2, 6]. Moreover, p16 mRNA levels differ between samples of young and old human skin [35], which supports our use of its qPCR-based quantification to distinguish follicular cells of young and old mice. The marker has also been applied, for more than 10 years, in analyses of processes associated with senescence caused by G1 arrest, and thus oncogenesis [36], as well as for monitoring tissue degeneration (which can be regarded as premature tissue aging) caused by gamma irradiation or cytotoxic drugs [37]. Irradiation was used as the inducing factor in our artificially triggered senescence experiments, in which we applied fractionated doses of IR based on recent literature [38, 39], clinical experience together with our previous knowledge and optimization. We did not apply a single high IR dose as in previous studies [40] to avoid the formation of postradiation skin lesions, which did not develop when using fractionated doses. Our approach opens new possibilities for research to find new drugs that can selectively eliminate senescent cells from organisms [41]. Thus, monitoring p16 and p21 mRNA levels by this method might replace laborious and less accurate methods, such as SA- $\beta$-gal assays in 'senolytics' research [42].

We also optimized the immunofluorescent (IF) approach for analyzing the collected follicular cells and thus monitoring selected proteins, including quantitative microscopy-based analysis of the DNA lesion marker $\gamma$-H2AX after gamma irradiation (Figure 5). For this, we developed software for routine evaluation of IDD by analysis of $\gamma-\mathrm{H} 2 \mathrm{AX}$ foci in z-stack images of individual hair follicles and investigation of acute DDR after IR, which was made publicly available (https://doi.org/10.6084/m9.figshare.14822643.v1). The temporal dynamics we observed in our samples are consistent with previous results [2,43] and generally, we proved that murine follicular cells can be used in IF assays of both nuclear and cytoplasmic proteins (Supplementary Figures 1, 2). It might be that the sensitivity of the method will be able to map functional differences between various GMO animals on the cellular level $[4,8]$. For example, GMO mice harboring changes in genes involved in DDR could reveal differences in the DNA repair dynamics within the nuclei of follicular cells. Moreover, such tests could be also performed ex-vivo, because collected follicular cells are viable [5], without compromising genome 
integrity [2], and can be kept alive for a significant time allowing various functional tests (Supplementary Figure 4). However, further research is needed to confirm such intriguing potential applications.

Last but not least, the method can be easily adapted for sampling other laboratory mammals, as hairs can be readily collected from rats, rabbits, dogs, monkeys, and even humans by the presented device (Supplementary Figure 4), opening a plethora of future research and biomedical applications.

\section{MATERIALS AND METHODS}

\section{Ethics statement}

All investigations were conducted following the ethical standards stated in the Declaration of Helsinki and other relevant national and international guidelines, with approval of the author's institutional review board.

\section{Mouse hair collection}

We collected each sample using an extraction device with modified pipette tips (described in patents EP2928382A1 and US 20150297253). We then placed the tips with the samples directly into $500 \mu \mathrm{l}$ portions of RNAlater (Qiagen, Hilden, Germany) for RT-qPCR analysis or $500 \mu \mathrm{l}$ of $10 \%$ neutral buffered formalin solution (Sigma-Aldrich, St. Louis, MO, USA) for immunofluorescence assays.

\section{Human hair collection and ex-vivo irradiation}

Hair follicles were collected from surface disinfected human calves and immediately put into the Dulbecco's modified Eagle's medium containing 4.5 g/l glucose (Biosera, Nuaille, France), supplemented with $10 \%$ fetal bovine serum (Gibco/Thermo Fisher Scientific, Grand Island, NY, USA) and $1 \%$ penicillin-streptomycin (Sigma-Aldrich). Samples were stored in the cell culture medium under normal cultivation conditions $(5 \% \mathrm{CO} 2$, $37^{\circ} \mathrm{C}, 100 \%$ humidity) during the necessary incubation steps until the fixation for immunofluorescence assays. Human hair follicle samples were irradiated on Petri dishes with DMEM culture medium using X-ray RS225M Research Cabinet (Xstrahl, Suwanee, GA, USA) with a 2 Gy dose. Samples were fixed $30 \mathrm{~min}$ after irradiation and processed in the same way as described below in the „Immunofluorescence and image acquisition" chapter.

\section{Irradiation}

Thirty C57Bl/6 wild-type mice (Envigo, Huntingdon, UK) were used in the first part of the study, 10 mice for each dose of ionizing radiation. An RS225M Research Cabinet (Xstrahl, Suwanee, GA, USA) was used to generate X-rays in all experiments. Each mouse was anesthetized with isoflurane (FORANE inhalation solution, Aesica, Hemel Hempstead, UK) before and during the application of the radiation. Only the right hind leg and adjacent parts of the body were irradiated, while the rest was covered by lead armor. Additionally, 10 mice Balb/cOlaHsd (Envigo, The Netherlands) were irradiated to induce senescence in muscle tissue with a fractionated dose of 3 x 8 Gy.

\section{Topical application of chemical clastogens}

HsdWin:NMRI mice (Envigo, Huntingdon, UK) females (3 animals per group) were treated with two clastogens (bleomycin or cis-platin) topically. Both compounds were dissolved in DMSO. We applied 16,6 $\mu \mathrm{l}$ of bleomycin solution $(5 \mu \mathrm{g} / \mathrm{ml})$ and $30 \mu \mathrm{l}$ of cisplatin solution $(0,5 \mathrm{mg} / \mathrm{ml})$. Each mouse was treated on the right body side by gentle rubbing of the compound into the skin. The treated spot had approximately $1,5 \mathrm{~cm}$ in diameter, each treated spot was marked. Bleomycintreated animals were incubated in their homecages for 1 hour and animals treated with cisplatin were incubated for 5 hours. Then we collected hair samples (treated samples from the marked spot, control samples from the left body side). All samples underwent IF staining for $\gamma$ $\mathrm{H} 2 \mathrm{AX}$ detection.

\section{DNA isolation and genotyping}

We genotyped the offspring (151 animals) of 5XFAD transgenic males (B6Cg-TgTg(APPSwFILon, PSEN1 *M146L*L286V)6799Vas/Mmjax) obtained from The Jackson Laboratory and C57B1/6 JOIaHsd females from Envigo (Huntingdon, UK) as genetic background. Genomic DNA was isolated from both mouse hair follicles and mouse tail biopsies with a Cobas ${ }^{\circledR}$ DNA Sample Preparation Kit (Roche, Basel, Switzerland) according to the manufacturer's instructions. The presence of APP and PST transgenes was confirmed by optimized PCR, the reaction mixture contained $2 \mu \mathrm{l}$ of template sample, $2 \mu \mathrm{l}$ of $10 \mu \mathrm{M}$ APP or PST primer mix, $2 \mu \mathrm{l}$ of $10 \mu \mathrm{M}$ internal control primer mix, $5 \mu \mathrm{l} 5 \mathrm{x}$ GC buffer, $0.5 \quad \mu l \quad 10 \quad \mathrm{mM}$ deoxyribonucleotide triphosphates (dNTPs), $0.75 \mu \mathrm{l}$ DMSO, $0.25 \mu \mathrm{l}$ Phusion ${ }^{\circledR}$ High-Fidelity DNA Polymerase) and 12,5 $\mu 1$ nuclease-free water (reagents from New England Biolabs, Ipswich, MA, USA). Primers are listed in Supplementary Table 1. Reactions were performed using the following program: $98^{\circ} \mathrm{C}$ for $30 \mathrm{~s}$, followed by 30 amplification cycles of $98^{\circ} \mathrm{C}$ for $10 \mathrm{~s}, 63^{\circ} \mathrm{C}$ for $30 \mathrm{~s}, 72^{\circ} \mathrm{C}$ for $10 \mathrm{~s}$, then $72^{\circ} \mathrm{C}$ for $5 \mathrm{~min}$ and cooling afterward. PCR products were visualized and checked using 1\% agarose/TBE gels and an Odyssey Fc 
electrophoresis system (LI-COR, Lincoln, NE, USA). The presence or absence of target genes was determined and animals were categorized as GMO-positive (with both transgenes present) or GMO-negative (lacking both genes). Each sample had to contain a band for internal control (bp).

\section{RNA extraction and reverse transcription}

Total RNA was extracted from hair stacks lysed in 700 $\mu l$ of QIAzol Lysis Reagent and processed immediately using a miRNeasy Mini Kit (Qiagen, Hilden, Germany) according to the manufacturer's recommended protocol, except the need to discard hair samples before solutions were transferred into columns. Finally, RNA from each sample was eluted into $30 \mu \mathrm{l}$ RNase-free water. RNA concentration and quality were assessed by a Nanodrop ND 1000 Spectrophotometer (ThermoScientific, Wilmington, DE, USA). To obtain cDNA, total RNA was used for reverse transcription using $18.9 \mu \mathrm{l}$ of each sample, mixed with $0.3 \mu \mathrm{g}$ of Random Primers (Promega, Madison, WI, USA) to a final volume of 19.5 $\mu \mathrm{l}$ and incubated at $70^{\circ} \mathrm{C}$ for $5 \mathrm{~min}$. Then, samples were cooled for $1 \mathrm{~min}$. A solution containing $6 \mu \mathrm{l}$ of RevertAid 5x RT buffer (Fermentas, Vilnius, Lithuania), $3 \mu \mathrm{l}$ of $10 \mathrm{mM}$ deoxyribonucleotide triphosphates (dNTPs), and $0.75 \mu \mathrm{l}$ of $40 \mathrm{U} / \mu \mathrm{l}$ RNAsin ribonuclease inhibitor (Promega) was added to each sample. The mixed solutions were incubated for $5 \mathrm{~min}$ at room temperature. In the last step, $150 \mathrm{U}(0.75 \mu \mathrm{l})$ of RevertAid Moloney Murine Leukemia Virus reverse transcriptase (Fermentas) was added to each sample. The final $30 \mu \mathrm{l}$ mixtures were incubated at room temperature for $10 \mathrm{~min}, 42^{\circ} \mathrm{C}$ for $60 \mathrm{~min}$, and $70^{\circ} \mathrm{C}$ for $10 \mathrm{~min}$. The resulting samples of cDNA were stored at $-20^{\circ} \mathrm{C}$. RNA for the subsequent aging experiment was obtained from mouse hair follicles of the mouse strain used for genotyping.

\section{Quantitative PCR (qPCR)}

For quantification of $p 21$, SENS1, MDM2 expression, as studied markers, and expression of HPRT as a housekeeping gene for relative quantification in the radiation experiment, real-time PCR was performed using a LightCycler 480 instrument (Roche). SYBR Green intercalation chemistry was used to detect the fluorescence signal and supplied software was used for $\mathrm{Ct}$ data generation and Tm analyses. An $18 \mu \mathrm{l}$ volume solution of each sample was mixed with $12.43 \mu 1$ DEPCtreated water (Ambion, Austin, TX, USA), $2 \mu \mathrm{l} 10 \mathrm{X}$ Thermo-Start PCR Buffer, $1.6 \mu \mathrm{l}$ of $25 \mathrm{mM} \mathrm{MgCl}$, and $0.2 \mu \mathrm{l}$ of $5 \mathrm{U} / \mu \mathrm{l}$ Thermo-Start Taq DNA Polymerase (Thermo Fisher Scientific, Waltham, MA, USA). A 0.61 $\mu l$ portion of $\mathrm{SYBR}^{\circledR}$ Green I nucleic acid gel stain $(10000 \mathrm{x}$ in DMSO) diluted in $10 \mathrm{mM}$ Tris- $\mathrm{HCl}$ buffer
pH 8 (Sigma-Aldrich) was added to each mixture, followed by $0.16 \mu \mathrm{l}$ of $25 \mathrm{mM}$ dNTPs (Promega) and 1 $\mu \mathrm{l}$ of a solution of specific primers for the selected marker and species. Specific oligonucleotides were custom synthesized by Generi Biotech (Hradec Králové, Czech Republic) and are presented in Supplementary Table 1. Reactions were performed in doublets using 2 $\mu \mathrm{l}$ cDNA. Touch-down programs were chosen for murine samples with the following cycling parameters: $95^{\circ} \mathrm{C}$ for $10 \mathrm{~min}$, then $95^{\circ} \mathrm{C}$ for $15 \mathrm{~s}$ and $67^{\circ} \mathrm{C}$ for $20 \mathrm{~s}$ with a target temperature of $62^{\circ} \mathrm{C}$ and $1^{\circ} \mathrm{C}$ steps for the first touchdown, and $95^{\circ} \mathrm{C}$ for $15 \mathrm{~s}$ and $60^{\circ} \mathrm{C}$ for $20 \mathrm{~s}$ with a target temperature of $58^{\circ} \mathrm{C}$ and $2^{\circ} \mathrm{C}$ steps for the second touchdown. Fluorescence signals were acquired during 50 cycles of $95^{\circ} \mathrm{C}$ for $15 \mathrm{~s}$ and $54^{\circ} \mathrm{C}\left(60^{\circ} \mathrm{C}\right.$ for $M D M 2)$ for $45 \mathrm{~s}$. For qPCR analyses of senescence marker ( $p 16$ or $p 21$ ) expression and housekeeping genes (GAPDH and ACTB), $2 \mu \mathrm{l}$ of cDNA of each sample was used within reaction mixtures further containing $10 \mu \mathrm{l}$ LightCycler 480 probes Master $2 \mathrm{x}$ conc. (Roche), $7 \mu 1$ LightCycler 480 Probes Master $\mathrm{H}_{2} \mathrm{O}$ PCR grade (Roche) and $1 \mu \mathrm{l}$ FAM-MGB Taqman probe (ThermoFisher Scientific). Reactions were performed using the following program: $95^{\circ} \mathrm{C}$ for $10 \mathrm{~min}$, followed by 50 amplification cycles of $95^{\circ} \mathrm{C}$ for $15 \mathrm{~s}$ and $60^{\circ} \mathrm{C}$ for $60 \mathrm{~s}$.

\section{Immunofluorescence and image acquisition}

Murine hair follicles for IF assays were obtained from HsdWin:NMRI mice (Envigo, UK). All samples were fixed in $10 \%$ neutral buffered formalin (Sigma-Aldrich) for $20 \mathrm{~min}$ and permeabilized with $0.5 \%$ TritonX-100 (Carl Roth $\mathrm{GmbH}+\mathrm{Co}$. KG, Karlsruhe, Germany) in phosphate-buffered saline (PBS) for $10 \mathrm{~min}$. After every step, samples were washed in PBS ( 2 x 2 min). Then they were blocked in PBS containing $1 \%$ bovine serum albumin (Sigma-Aldrich) for $20 \mathrm{~min}$. The blocking solution was also used to dilute the antibodies. Samples were incubated in primary antibody solution overnight at $4^{\circ} \mathrm{C}$. After washing with PBS, samples were incubated in secondary antibody solution for one hour. The primary and secondary antibodies are listed in Supplementary Tables 2, 3. Samples were washed in PBS and mounted using Vectashield antifade medium with DAPI (Vector Laboratories, Burlingame, CA, USA). Images of mouse hair follicles were obtained using an Axio Observer.Z1/Cell Observer Spinning Disc microscopic system (Zeiss, Oberkochen, Germany) with a $63 x$ oil objective. All images were processed using ZEN Blue Image processing software (Zeiss).

\section{Giemsa - Romanowsky staining}

To investigate the mouse hair follicle cells' general morphology, we used classical Giemsa-Romanowsky 
staining, as follows. Immediately after collecting samples of murine hairs in collection tips they were incubated in $4 \%$ methanol solution for $15 \mathrm{~min}$, washed three times for $2 \mathrm{~min}$ in PBS, then soaked for 30 seconds in May - Grünwald solution (Penta, Prague, Czech Republic) and subsequently rinsed in distilled water for $2 \mathrm{~min}$, gently dried and finally incubated in 10x diluted Giemsa-Romanowsky solution (Penta). The rest of the staining solution was discarded by washing the samples in distilled water for 2 min. Hair endings with follicles were cut and placed between a microscopic glass and coverslip in a water drop. Images were obtained at $20 \mathrm{x}$ or $100 \mathrm{x}$ magnification with a transmission light microscope (Zeiss, Primo Vert).

\section{Data processing and statistical analyses}

Matlab R2017a and Microsoft Excel were used for all data processing analyses and visualizations. Fold changes in gene expression were calculated from qPCR data using the $\Delta \Delta \mathrm{Ct}$ method, with averages of raw technical measurements as the inputs. The KruskalWallis test was used for irradiation-dependence verification of the results at zero doses. T-tests were used to investigate differences between irradiated and non-irradiated samples at each time point. T-tests were also used to generate p-values describing the significance of differences between old and young animals and between variables measured at the zerotime point and all other time points in both irradiated and control hind legs in the radiation-induced senescence experiment. In $\gamma-\mathrm{H} 2 \mathrm{AX}$ analyses, green dots and areas were sought in z-stack images (in tiff format) of DAPI-stained tissues. Two median filters were used for automatic identification of the foci and suppression of background signals. The intensity of DNA damage (IDD) was calculated as shares of the signals and DAPI area, where one data point represents the average value from z-stack images from one hair follicle. The software with example 6 Gy data set is publically available on the Figshare platform at the following link: https://doi.org/10.6084/m9.figshare.14822643.v1. The Kruskal-Wallis test was used to test the null hypothesis that there was no treatment- or samplerelated differences in technical measurements.

\section{AUTHOR CONTRIBUTIONS}

MH, MM, JB, and JS designed the experiments and interpreted data. qPCR experiments were performed by NK and HS. Microscopy experiments were performed by MM, HS, and NK. Animal handling, sample collection, and sample ex-vivo treatments were done by NK, HS, and PD. TF developed and programmed a method for quantitative analysis of microscopic images. $\mathrm{MM}, \mathrm{NK}, \mathrm{HS}, \mathrm{JB}$, and MH wrote the manuscript.

\section{ACKNOWLEDGMENTS}

We gratefully acknowledge expert assistance in sample collection by Katerina Frantikova and Tereza Schneiderova and partial assistance in sample preparation for RT-qPCR set-up by Petra Svarcova and Tereza Lausova during their internship at our institute.

\section{CONFLICTS OF INTEREST}

MM, JB, MH are co-inventors on patents EP2928382A1 and US 20150297253, utilizing the method for extraction of follicular cells and device for the pursuance of this method. All authors declare they have no conflicts of interest.

\section{FUNDING}

The study was supported by MEYS CR: (Large RI Project LM2018129 - Czech-BioImaging), ERDF (project No. CZ.02.1.01./0.0/0.0./16_013/0001775), ENOCH project (No. CZ.02.1.01/0.0/0.0/16_019/ 0000868), and Czech national node of the European infrastructure for translational medicine (LM2018133), Technological Agency of the Czech Republic (TN01000013), Grant of the Czech Ministry of Interior (VG20102014001), The Novo Nordisk Foundation (16854 and 0060590), The Swedish Research Council VR-MH 2014-46602-117891-30, The Swedish Cancer Foundation/Cancerfonden (\# 170176) and The Danish National Research Foundation (project CARD, DNRF 125).

\section{REFERENCES}

1. Green MR, Clay CS, Gibson WT, Hughes TC, Smith CG, Westgate GE, White M, Kealey T. Rapid isolation in large numbers of intact, viable, individual hair follicles from skin: biochemical and ultrastructural characterization. J Invest Dermatol. 1986; 87:768-70.

https://doi.org/10.1111/1523-1747.ep12457348 PMID:3782859

2. Redon CE, Nakamura AJ, Gouliaeva K, Rahman A, Blakely WF, Bonner WM. The use of gamma-H2AX as a biodosimeter for total-body radiation exposure in nonhuman primates. PLoS One. 2010; 5:e15544. https://doi.org/10.1371/journal.pone.0015544 PMID:21124906

3. Bhogal N, Kaspler P, Jalali F, Hyrien O, Chen R, Hill RP, Bristow RG. Late residual gamma-H2AX foci in murine skin are dose responsive and predict radiosensitivity in vivo. Radiat Res. 2010; 173:1-9.

https://doi.org/10.1667/RR1851.1

PMID:20041754 
4. Wang GY, Wang J, Mancianti ML, Epstein EH Jr. Basal cell carcinomas arise from hair follicle stem cells in Ptch1(+/-) mice. Cancer Cell. 2011; 19:114-24. https://doi.org/10.1016/i.ccr.2010.11.007 PMID:21215705

5. Yamaguchi A, Matsumura R, Matsuzaki T, Nakamura W, Node K, Akashi M. A simple method using ex vivo culture of hair follicle tissue to investigate intrinsic circadian characteristics in humans. Sci Rep. 2017; 7:6824.

https://doi.org/10.1038/s41598-017-07268-8

PMID: $\underline{28755004}$

6. Randall KJ, Foster JR. The demonstration of immunohistochemical biomarkers in methyl methacrylate-embedded plucked human hair follicles. Toxicol Pathol. 2007; 35:952-57.

https://doi.org/10.1080/01926230701748198

PMID:18098041

7. Watts LM, Browne JA, Murphy BA. Investigation of a non-invasive method of assessing the equine circadian clock using hair follicle cells. J Circadian Rhythms. 2012; 10:7.

https://doi.org/10.1186/1740-3391-10-7

PMID:23039139

8. Chou WC, Takeo M, Rabbani P, Hu H, Lee W, Chung YR, Carucci J, Overbeek $P$, Ito $M$. Direct migration of follicular melanocyte stem cells to the epidermis after wounding or UVB irradiation is dependent on Mc1r signaling. Nat Med. 2013; 19:924-29.

https://doi.org/10.1038/nm.3194 PMID:23749232

9. Aoki H, Hara A, Motohashi T, Kunisada T. Keratinocyte stem cells but not melanocyte stem cells are the primary target for radiation-induced hair graying. J Invest Dermatol. 2013; 133:2143-51.

https://doi.org/10.1038/iid.2013.155 PMID:23549419

10. Paus R, Cotsarelis G. The biology of hair follicles. N Engl J Med. 1999; 341:491-97.

https://doi.org/10.1056/NEJM199908123410706

PMID:10441606

11. Griñán-Ferré $C$, Sarroca $S$, Ivanova A, Puigoriol-Illamola D, Aguado F, Camins A, Sanfeliu C, Pallàs M. Epigenetic mechanisms underlying cognitive impairment and Alzheimer disease hallmarks in 5XFAD mice. Aging (Albany NY). 2016; 8:664-84.

https://doi.org/10.18632/aging.100906

PMID:27013617

12. Kritsilis M, V Rizou S, Koutsoudaki PN, Evangelou K, Gorgoulis VG, Papadopoulos D. Ageing, Cellular Senescence and Neurodegenerative Disease. Int J Mol Sci. 2018; 19:2937. https://doi.org/10.3390/ijms19102937 PMID: 30261683
13. Mayer C, Popanda O, Greve B, Fritz E, Illig T, EckardtSchupp F, Gomolka M, Benner A, Schmezer P. A radiation-induced gene expression signature as a tool to predict acute radiotherapy-induced adverse side effects. Cancer Lett. 2011; 302:20-28.

https://doi.org/10.1016/i.canlet.2010.12.006 PMID:21236564

14. Kabacik S, Ortega-Molina A, Efeyan A, Finnon $P$, Bouffler S, Serrano M, Badie C. A minimally invasive assay for individual assessment of the ATM/CHEK2/p53 pathway activity. Cell Cycle. 2011; 10:1152-61.

https://doi.org/10.4161/cc.10.7.15231 PMID:21389785

15. Gire V, Roux P, Wynford-Thomas D, Brondello JM, Dulic V. DNA damage checkpoint kinase Chk2 triggers replicative senescence. EMBO J. 2004; 23:2554-63. https://doi.org/10.1038/sj.emboj.7600259 PMID:15192702

16. Campisi J. Cancer, aging and cellular senescence. In Vivo. 2000; 14:183-88. PMID:10757076

17. Itahana K, Dimri G, Campisi J. Regulation of cellular senescence by p53. Eur J Biochem. 2001; 268:2784-91. https://doi.org/10.1046/j.1432-1327.2001.02228.x PMID:11358493

18. Evangelou K, Lougiakis N, Rizou SV, Kotsinas A, Kletsas D, Muñoz-Espín D, Kastrinakis NG, Pouli N, Marakos P, Townsend P, Serrano M, Bartek J, Gorgoulis VG. Robust, universal biomarker assay to detect senescent cells in biological specimens. Aging Cell. 2017; 16:192-97. https://doi.org/10.1111/acel.12545 PMID:28165661

19. Collado M, Serrano M. Senescence in tumours: evidence from mice and humans. Nat Rev Cancer. 2010; 10:51-57. https://doi.org/10.1038/nrc2772 PMID:20029423

20. Brown JP, Wei W, Sedivy JM. Bypass of senescence after disruption of p21CIP1/WAF1 gene in normal diploid human fibroblasts. Science. 1997; 277:831-34. https://doi.org/10.1126/science.277.5327.831 PMID: $\underline{9242615}$

21. Hall BM, Balan V, Gleiberman AS, Strom E, Krasnov $P$, Virtuoso LP, Rydkina E, Vujcic S, Balan K, Gitlin I, Leonova K, Polinsky A, Chernova OB, Gudkov AV. Aging of mice is associated with p16(Ink4a)- and $\beta$ galactosidase-positive macrophage accumulation that can be induced in young mice by senescent cells. Aging (Albany NY). 2016; 8:1294-315.

https://doi.org/10.18632/aging.100991 PMID:27391570

22. Liu JY, Souroullas GP, Diekman BO, Krishnamurthy J, Hall BM, Sorrentino JA, Parker JS, Sessions GA, 
Gudkov AV, Sharpless NE. Cells exhibiting strong p16 ${ }^{\text {INK4a }}$ promoter activation in vivo display features of senescence. Proc Natl Acad Sci USA. 2019; 116:2603-11.

https://doi.org/10.1073/pnas.1818313116

PMID:30683717

23. Sherr CJ, DePinho RA. Cellular senescence: mitotic clock or culture shock? Cell. 2000; 102:407-10.

https://doi.org/10.1016/s0092-8674(00)00046-5

PMID:10966103

24. Wright WE, Shay JW. Telomere dynamics in cancer progression and prevention: fundamental differences in human and mouse telomere biology. Nat Med. 2000; 6:849-51.

https://doi.org/10.1038/78592 PMID:10932210

25. Rodier F, Coppé JP, Patil CK, Hoeijmakers WA, Muñoz DP, Raza SR, Freund A, Campeau E, Davalos AR, Campisi J. Persistent DNA damage signalling triggers senescence-associated inflammatory cytokine secretion. Nat Cell Biol. 2009; 11:973-79. https://doi.org/10.1038/ncb1909 PMID:19597488

26. Tsai KK, Stuart J, Chuang YY, Little JB, Yuan ZM. Lowdose radiation-induced senescent stromal fibroblasts render nearby breast cancer cells radioresistant. Radiat Res. 2009; 172:306-13. https://doi.org/10.1667/RR1764.1 PMID:19708779

27. Guillon J, Petit C, Moreau M, Toutain B, Henry C, Roché $\mathrm{H}$, Bonichon-Lamichhane N, Salmon JP, Lemonnier J, Campone $\mathrm{M}$, Verrièle $\mathrm{V}$, Lelièvre $\mathrm{E}$, Guette $\mathrm{C}$, Coqueret $\mathrm{O}$. Regulation of senescence escape by TSP1 and CD47 following chemotherapy treatment. Cell Death Dis. 2019; 10:199.

https://doi.org/10.1038/s41419-019-1406-7

PMID:30814491

28. Li M, You L, Xue J, Lu Y. Ionizing Radiation-Induced Cellular Senescence in Normal, Non-transformed Cells and the Involved DNA Damage Response: A Mini Review. Front Pharmacol. 2018; 9:522. https://doi.org/10.3389/fphar.2018.00522 PMID:29872395

29. Schmitteckert EM, Prokop CM, Hedrich HJ. DNA detection in hair of transgenic mice--a simple technique minimizing the distress on the animals. Lab Anim. 1999; 33:385-89. https://doi.org/10.1258/002367799780487922 PMID:10778788

30. Meldgaard $\mathrm{M}$, Bollen PJ, Finsen B. Non-invasive method for sampling and extraction of mouse DNA for PCR. Lab Anim. 2004; 38:413-17. https://doi.org/10.1258/0023677041958981 PMID:15479556
31. Picazo M, García-olmo D. DNA from tissues of young mice is optimal for genotyping. Electronic Journal of Biotechnology. 2015; 18:83-87.

https://www.sciencedirect.com/science/article/pii/S07 $1734581400147 \mathrm{X}$ https://doi.org/10.1016/i.ejbt.2014.12.002

32. Paul S, Amundson SA. Development of gene expression signatures for practical radiation biodosimetry. Int J Radiat Oncol Biol Phys. 2008; 71:1236-44. https://doi.org/10.1016/i.ijrobp.2008.03.043 PMID: 18572087

33. Kabacik S, Manning G, Raffy C, Bouffler S, Badie C. Time, dose and ataxia telangiectasia mutated (ATM) status dependency of coding and noncoding RNA expression after ionizing radiation exposure. Radiat Res. 2015; 183:325-37. https://doi.org/10.1667/RR13876.1 PMID:25738893

34. Albrecht H, Durbin-Johnson B, Yunis R, Kalanetra KM, $\mathrm{Wu} S$, Chen R, Stevenson TR, Rocke DM. Transcriptional response of ex vivo human skin to ionizing radiation: comparison between low- and highdose effects. Radiat Res. 2012; 177:69-83. https://doi.org/10.1667//rr2524.1 PMID:22029842

35. Ressler S, Bartkova J, Niederegger H, Bartek J, Scharffetter-Kochanek K, Jansen-Dürr $P$, Wlaschek M. p16INK4A is a robust in vivo biomarker of cellular aging in human skin. Aging Cell. 2006; 5:379-89. https://doi.org/10.1111/i.1474-9726.2006.00231.x PMID:16911562

36. Lukas J, Sørensen CS, Lukas C, Santoni-Rugiu E, Bartek J. p16INK4a, but not constitutively active pRb, can impose a sustained G1 arrest: molecular mechanisms and implications for oncogenesis. Oncogene. 1999; 18:3930-35.

https://doi.org/10.1038/sj.onc.1202777 PMID:10435615

37. Nasto LA, Wang D, Robinson AR, Clauson CL, Ngo K, Dong $\mathrm{Q}$, Roughley $\mathrm{P}$, Epperly M, Huq SM, Pola E, Sowa G, Robbins PD, Kang J, et al. Genotoxic stress accelerates age-associated degenerative changes in intervertebral discs. Mech Ageing Dev. 2013; 134:35-42. https://doi.org/10.1016/i.mad.2012.11.002 PMID:23262094

38. Seol MA, Jung U, Eom HS, Kim SH, Park HR, Jo SK. Prolonged expression of senescence markers in mice exposed to gamma-irradiation. J Vet Sci. 2012; 13:331-38.

https://doi.org/10.4142/jvs.2012.13.4.331 PMID:23271173

39. Kim BC, Yoo HJ, Lee HC, Kang KA, Jung $\mathrm{SH}$, Lee $\mathrm{HJ}$, Lee $M$, Park S, Ji YH, Lee YS, Ko YG, Lee JS. Evaluation of 
premature senescence and senescence biomarkers in carcinoma cells and xenograft mice exposed to single or fractionated irradiation. Oncol Rep. 2014; 31:2229-35.

https://doi.org/10.3892/or.2014.3069 PMID:24626611

40. Peng $X$, Wu $Y$, Brouwer $U$, van Vliet $T$, Wang B, Demaria M, Barazzuol L, Coppes RP. Cellular senescence contributes to radiation-induced hyposalivation by affecting the stem/progenitor cell niche. Cell Death Dis. 2020; 11:854.

https://doi.org/10.1038/s41419-020-03074-9

PMID:33056980

41. Lee $S$, Schmitt CA. The dynamic nature of senescence in cancer. Nat Cell Biol. 2019; 21:94-101. https://doi.org/10.1038/s41556-018-0249-2 PMID:30602768
42. Capparelli C, Chiavarina B, Whitaker-Menezes D, Pestell TG, Pestell RG, Hulit J, Andò S, Howell A, Martinez-Outschoorn UE, Sotgia F, Lisanti MP. CDK inhibitors (p16/p19/p21) induce senescence and autophagy in cancer-associated fibroblasts, "fueling" tumor growth via paracrine interactions, without an increase in neo-angiogenesis. Cell Cycle. 2012; 11:3599-610.

https://doi.org/10.4161/cc.21884

PMID:22935696

43. Suzuki K, Nakashima M, Yamashita S. Dynamics of ionizing radiation-induced DNA damage response in reconstituted three-dimensional human skin tissue. Radiat Res. 2010; 174:415-23. https://doi.org/10.1667/RR2007.1 PMID:20726705 


\section{SUPPLEMENTARY MATERIALS}

\section{Supplementary Figures}

A

DAPI

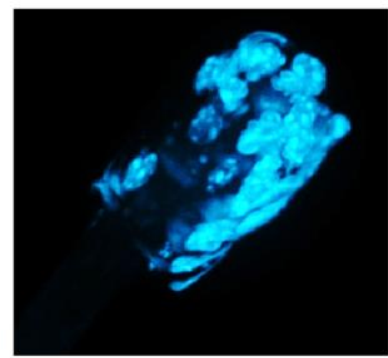

B

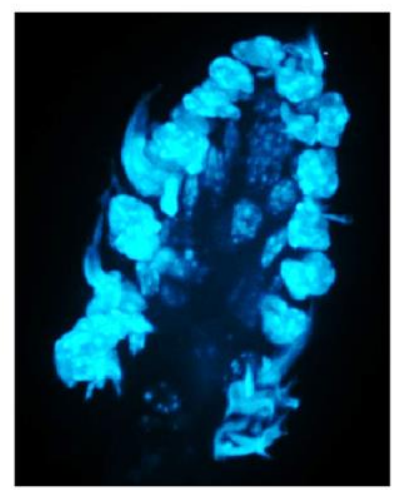

MDM2
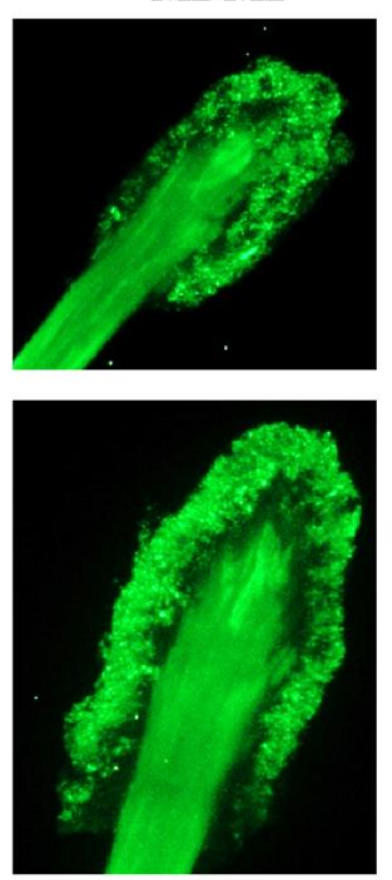

p53
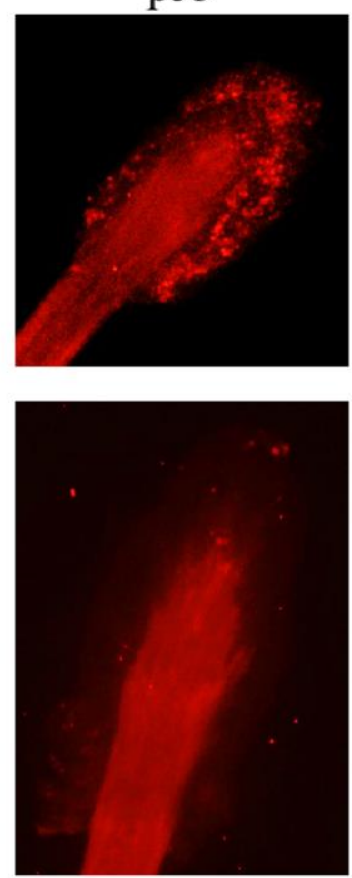

merge
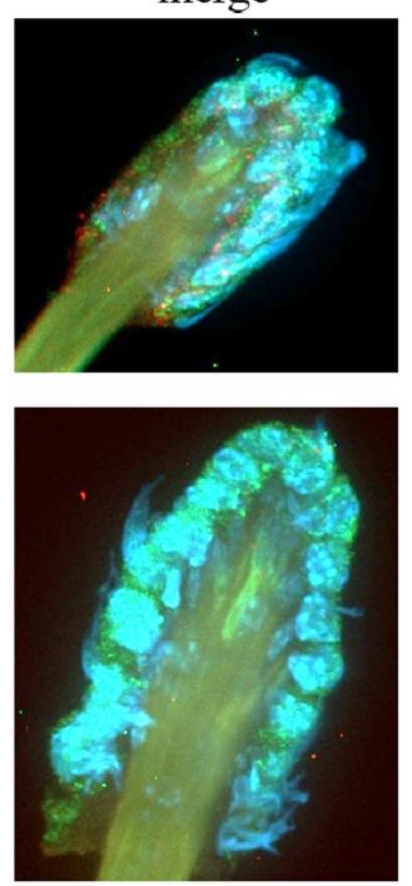

Supplementary Figure 1. Immunofluorescent detection of MDM2 and p53 proteins in murine hair follicles. (A) Representative images of a hair follicle as maximum intensity projections from z-stack scanning with a confocal spinning disc microscope. Nuclei are stained with DAPI, green and red autofluorescence is visible in a hair shaft. (B) Representative images for autofluorescence estimation in the red channel. No primary antibody for p53 was used to show the difference between autofluorescence and real signals in the red channel. Magnification 60x objective with oil immersion. 
DAPI
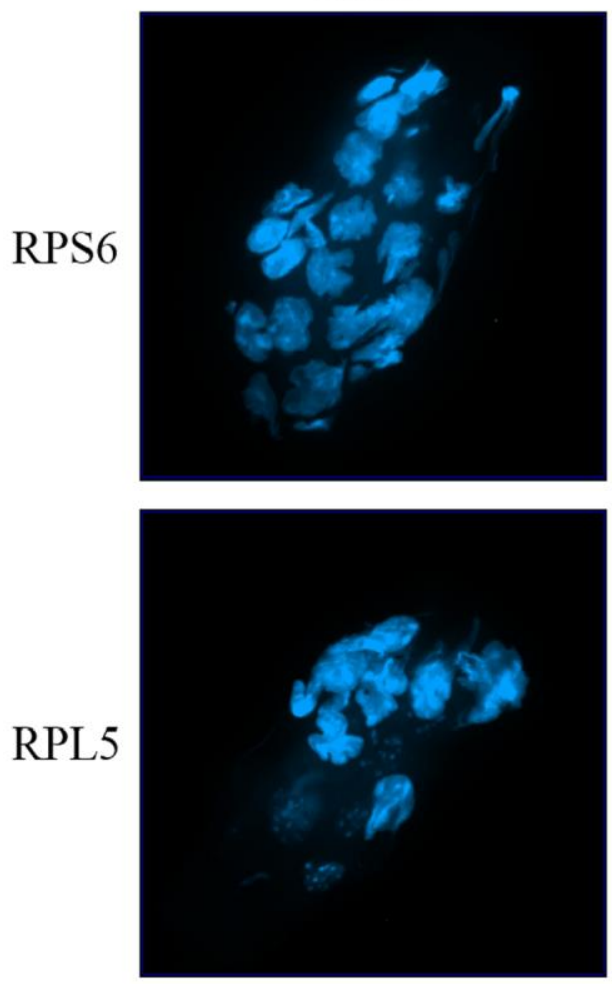

ribosomal protein
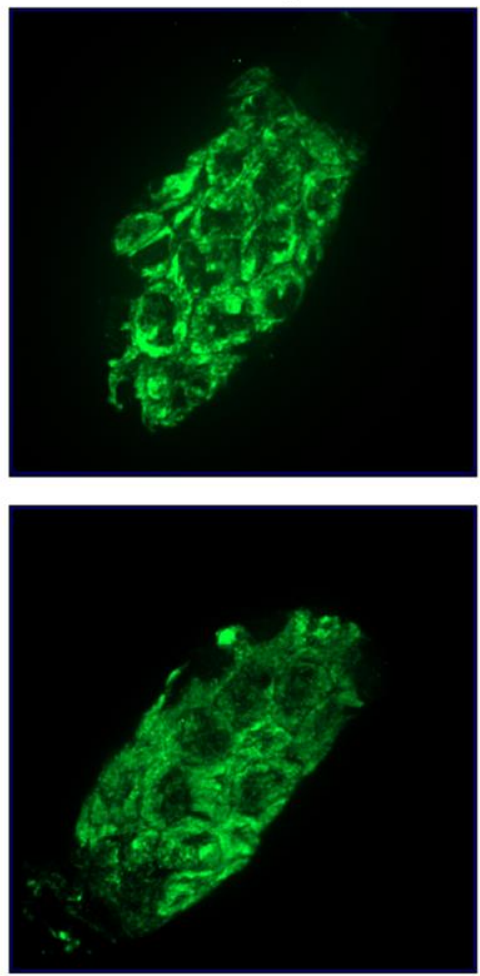

merge
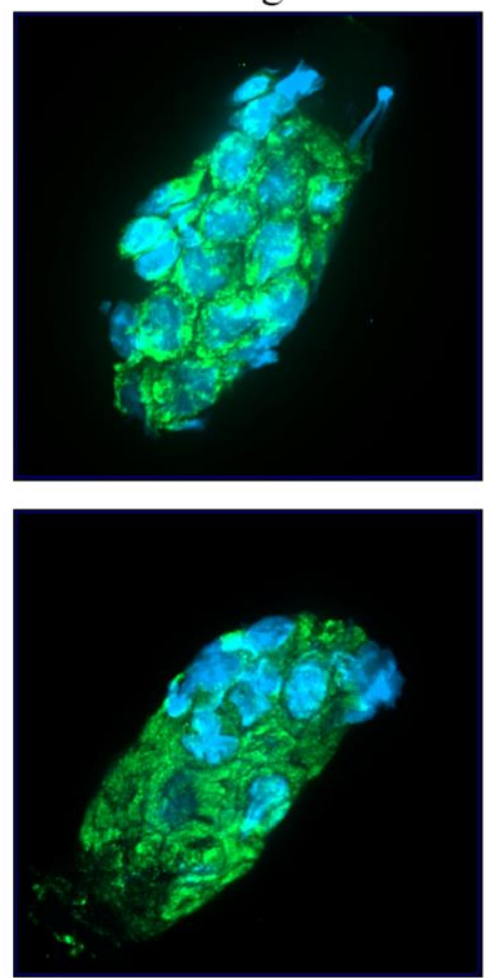

Supplementary Figure 2. Example of immunofluorescent detection of cytoplasmic proteins - ribosomal proteins RPS6 and RPL5 in murine hair follicles. Nuclei are stained with Hoechst 33342 and shown in the blue channel, ribosomal proteins are shown in the green channel. Representative images were obtained from z-stack scanning with a confocal spinning disc microscope. Magnification 60x objective with oil immersion. 

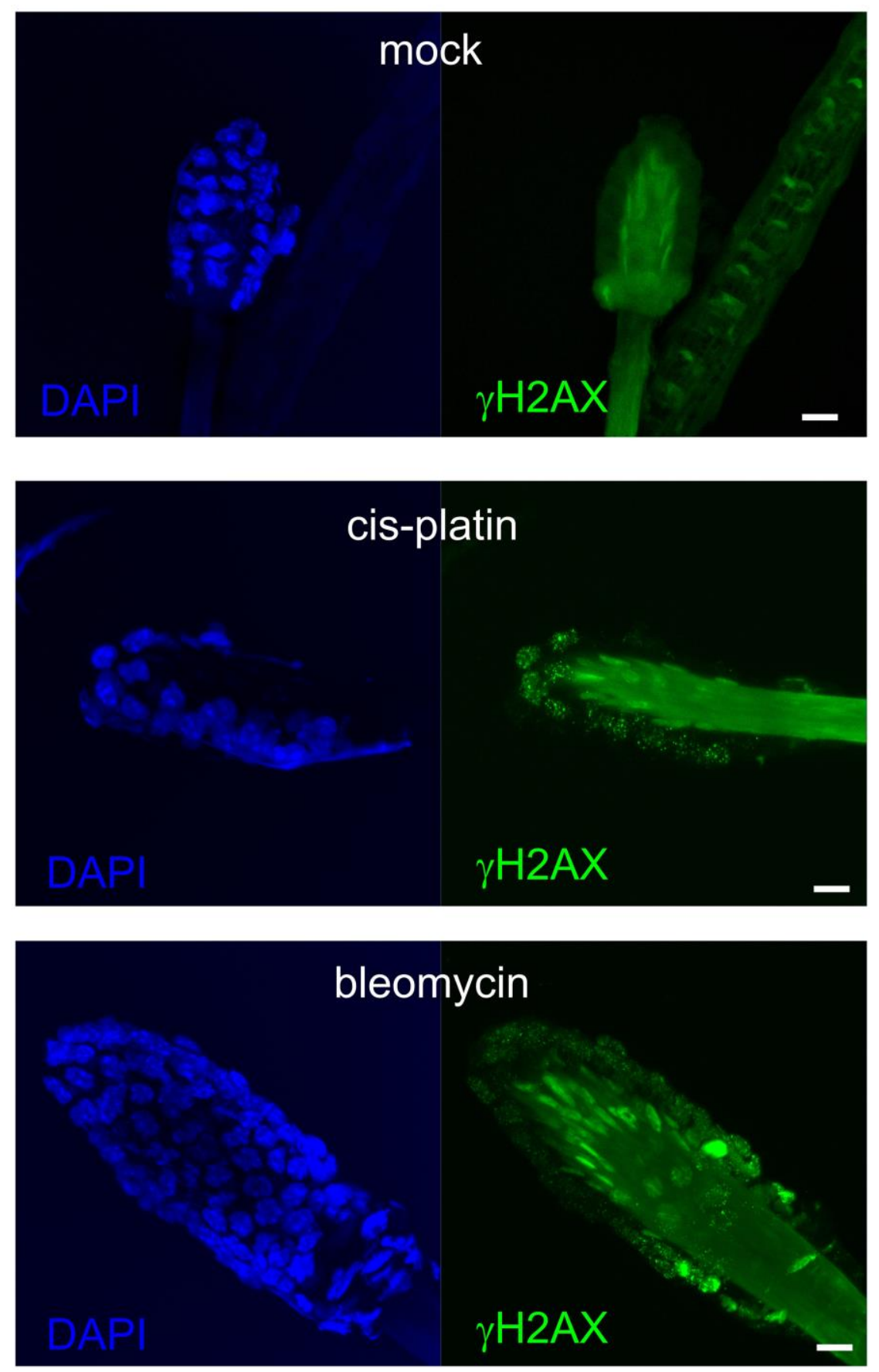

Supplementary Figure 3. Immunofluorescent detection of $\mathrm{Y}-\mathrm{H} 2 \mathrm{AX}$ in murine hair follicles after the treatment with topically applied clastogens (bleomycin and cisplatin). 
A

Hair collection
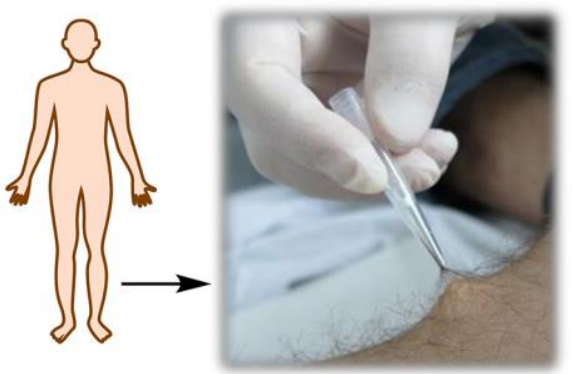

Transfer into cell media

Ex-vivo treatment

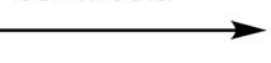
(X-ray irradiation)

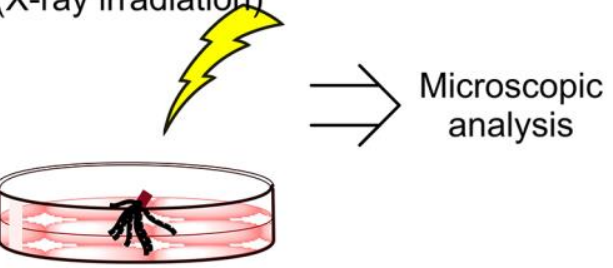

B
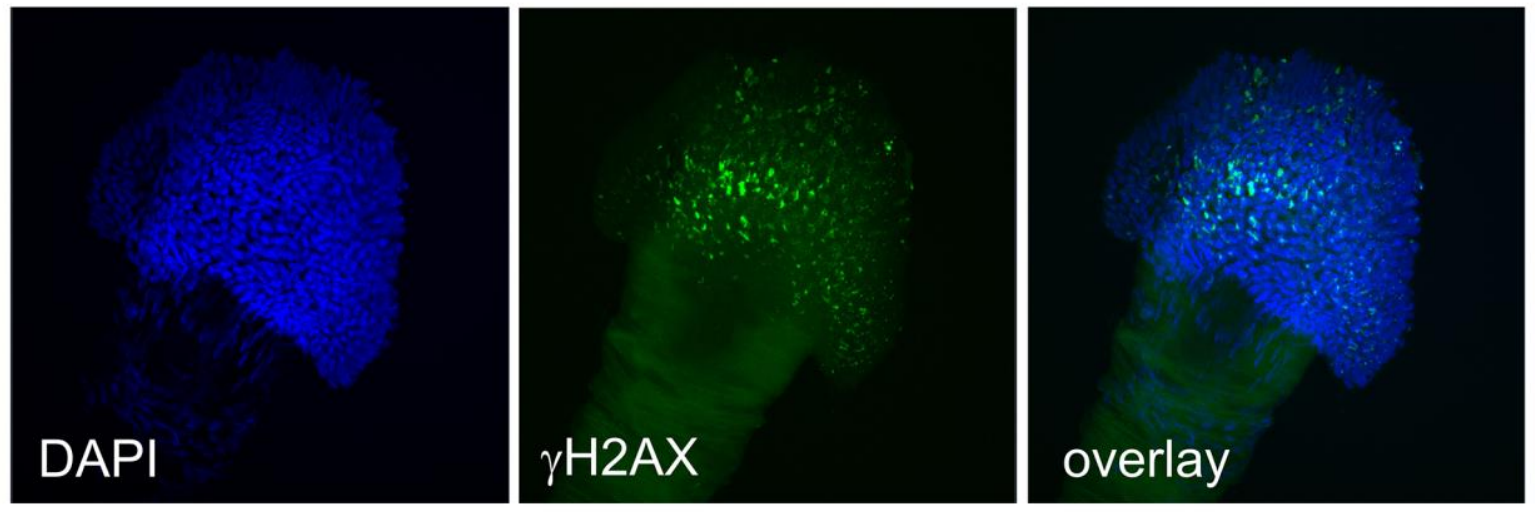

C
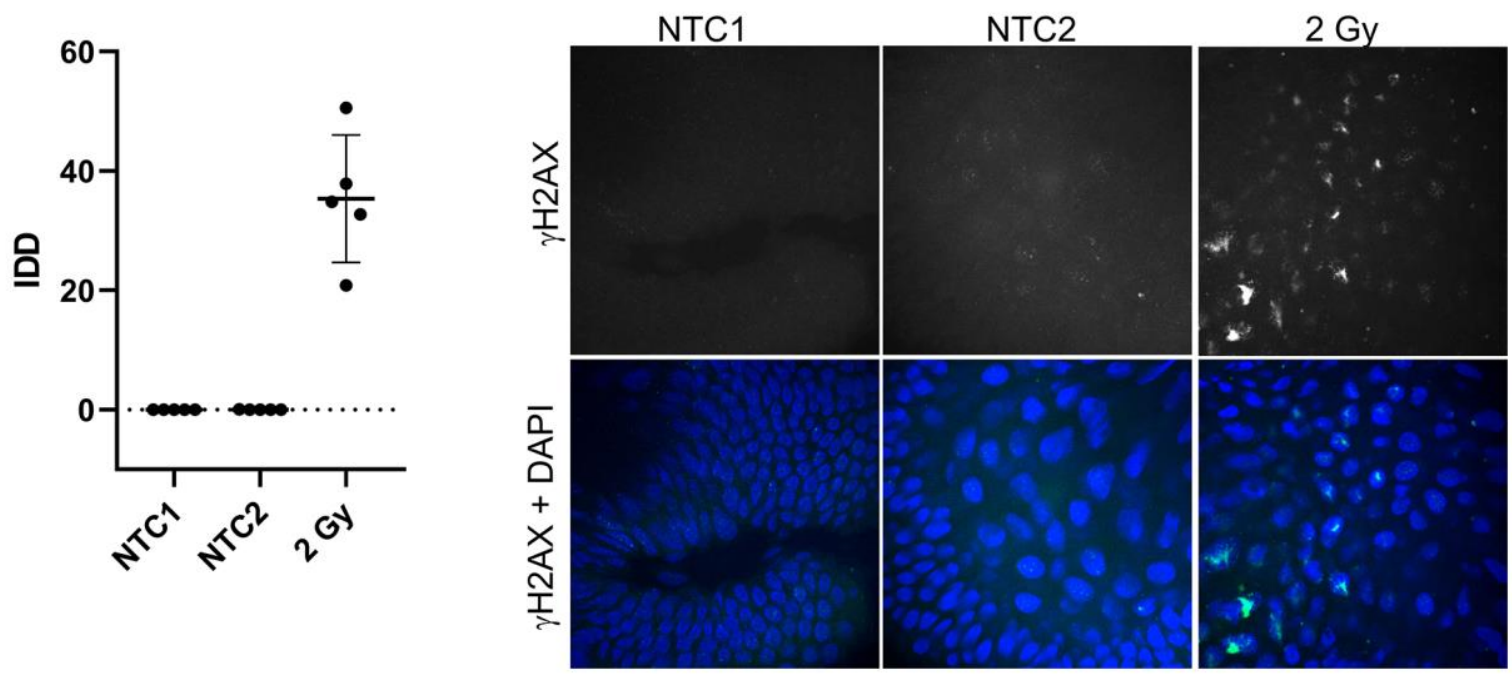

Supplementary Figure 4. Immunofluorescent detection of $\boldsymbol{\gamma}-\mathrm{H} 2 \mathrm{AX}$ in human hair follicles. (A) Scheme of the experimental workflow. (B) Representative image of human hair follicle ex-vivo irradiated by 2 Gy of ionizing irradiation. Nuclei stained with DAPI (blue), $\gamma$ $\mathrm{H} 2 \mathrm{AX}$ (green). Hair shaft autofluorescence is also visible in the green channel. (C) Results of image analyses in terms of IDD (intensity of DNA damage), with each data point representing the area of the $\mathrm{y}-\mathrm{H} 2 \mathrm{AX}$ signal related to the area of the nuclei in one scanned hair follicle in $\mathrm{z}-$ stack mode and representative images used in the computational analyses of one z-stack layer. NTC1 and 2 are the non-irradiated controls. NTC1 was fixed immediately after the collection and NTC2 was incubated for 30 min in cell media, as well as the 2 Gy samples after irradiation. 


\section{Supplementary Tables}

Supplementary Table 1. Primers for PCR.

\begin{tabular}{|c|c|c|c|c|}
\hline Type & Gene & Forward primer 5' - 3', & Reverse primer 5' - 3' & Amplicon \\
\hline mRNA & $H P R T$ & GGACAGGACTGAAAGACTTG & TAATCCAGCAGGTCAGCAAA & 114 bps \\
\hline mRNA & $p 21$ & GCAAGAGAAAACCCTGAAGTG & CACACAGAGTGAGGGCTAAG & $100 \mathrm{bps}$ \\
\hline mRNA & SESN1 & CCATAGGCCTTGGCTGATTA & TCCACACTGTGATTGCCATT & $246 \mathrm{bps}$ \\
\hline \multirow[t]{2}{*}{ mRNA } & $M D M 2 X 1$ & TGCAAGCACCTCACAGATTC & ACACAATGTGCTGCTGCTTC & $188 \mathrm{bps}$ \\
\hline & $M D M 2 X 1+X 2$ & ATGAATCСТССССТTССАТС & CTGTCAGCTTTTTGCCATCA & $169 \mathrm{bps}$ \\
\hline DNA & $A P P$ & AGGACTGACCACTCGACCAG & CGGGGGTCTAGTTCTGCAT & $377 \mathrm{bps}$ \\
\hline
\end{tabular}

Two pairs of primers were designed for MDM2. One (MDM2 X1) only covers transcript variant 1 (NM_010786.4) and the other (MDM2 X1+X2) covers both known variants (NM_001288586.2 as well as NM_010786.4). Amplicon lengths for each marker were verified using an Agilent Bioanalyzer 2100 and Agilent DNA 1000 Kit. Primers for both transgenes (APP and PST) and internal controls were designed and their sequences were provided by the Jackson Laboratory.

Supplementary Table 2. Primary antibodies.

\begin{tabular}{lccccc}
\hline Antigen & Species & Company & Catalog no. & Dilution & Application \\
\hline p16 & Mouse & Santa Cruz Biotechnology & sc-1661 & $1: 100$ & IF \\
H2AX & Rabbit & Cell Signaling & $\# 9718$ & $1: 400$ & IF \\
MDM2 & Mouse & Abcam & ab16895 & $1: 200$ & IF \\
p53 & Rabbit & Santa Cruz Biotechnology & Sc-6243 & $1: 100$ & IF \\
RPS6 & Rabbit & Cell Signaling & $\# 2217$ & $1: 100$ & IF \\
RPL5 & Rabbit & Cell Signaling & $\# 14568$ & $1: 100$ & IF \\
\hline
\end{tabular}

Supplementary Table 3. Secondary antibodies.

\begin{tabular}{llccccc}
\hline Host & Recognizes & Fluorophore & Company & Catalog no. & Dilution & Application \\
\hline Goat & Mouse IgG & Alexa Fluor 488 & ThermoFisher & A-1101 & $1: 1000$ & IF \\
Goat & Rabbit IgG & Alexa Fluor 488 & ThermoFisher & A-11034 & $1: 1000$ & IF \\
Goat & Rabbit IgG & Alexa Fluor 488 & Abcam & ab150077 & $1: 1000$ & IF \\
\hline
\end{tabular}




\section{Supplementary Video}

Please browse Full Text version to see the data of Supplementary Video 1.

Supplementary Video 1 . Collection of hair samples using the vacuum collector invented by our team. 